\title{
Revista
}

(Rgp)) Gestão \& Políticas Públicas

Artigo

\section{Um Olhar Retrospectivo sobre os Correspondentes Bancários: sete notas para uma história do branchless banking brasileiro}

\author{
A Retrospective Look at Banking Correspondents: seven notes for a history of \\ Brazilian branchless banking
}

Una Mirada Retrospectiva sobre los Correspondientes Bancarios: siete notas para una historia del branchless banking brasileño

Martin Jayo ${ }^{1}$

\footnotetext{
${ }^{1}$ Filiação institucional. Doutor em Administração pela FGV-EAESP, mestre em Ciências da Comunicação pela ECA-USP (2005) e graduado em Economia pela FEA-USP. Professor nos cursos de Bacharelado e Mestrado em Gestão de Políticas Públicas da Escola de Artes, Ciências e Humanidades da Universidade de São Paulo, São Paulo, SP, Brasil.

Correspondência: E-mail: martin.jayo@usp.br
}

Resumo $\quad$ O artigo reúne sete notas, escritas entre 2007 e 2010, sobre o surgimento e desenvolvimento dos correspondentes bancários (CBs) como importante canal de distribuição de serviços financeiros no Brasil. Ao fazer isso, mostra como ele cresceu na esteira de políticas públicas de inclusão social e financeira.

Palavras-chaves: Tecnologia Bancária, Correspondentes Bancários, Branchless Banking, Serviços Financeiros, Inclusão Social

Abstract The paper presents seven notes, written between 2007 and 2010, about the emergence and development of banking correspondents (CBs) as a popular channel for bank services in Brazil. By doing so, it shows how the growth of CBs has been influenced by public policies for social and financial inclusion.

Keywords: Banking Technology, Banking Correspondents, Branchless Banking, Financial Services, Social Inclusion 
Resumen El artículo reúne siete notas, escritas entre 2007 y 2010, sobre el surgimiento y desarrollo de correspondientes bancarios (CBs) como importante canal de distribución se servicios financieros en Brasil. Al hacerlo, presenta muestra de qué forma el canal creció influenciado por políticas publicas de inclusión social y financiera.

Palabras Clave: Tecnología Bancaria, Correspondientes Bancarios, Branchless Banking, Servicios Financieros, Inclusión Social 


\section{Introdução}

$\mathrm{Na}$ década de 2000, o sistema bancário brasileiro experimentou uma expansão sem precedentes na extensão e capilaridade de suas redes físicas de atendimento, com o surgimento de um novo canal de distribuição intensamente apoiado em tecnologias de informação e comunicação (TIC). Trata-se da inovação que ficou conhecida como "correspondentes bancários" (CBs), nome dado a uma grande variedade de comércios e outros estabelecimentos não bancários, tais como supermercados, mercearias, farmácias, casas lotéricas, agências postais, etc., que passaram a ser contratados e habilitados como pontos de acesso a serviços dos bancos, tanto púbicos como privados.

A infraestrutura tecnológica do novo canal costuma basear-se em equipamentos POS (point of sale), semelhantes aos utilizados para pagamentos com cartão de crédito ou débito, ou então microcomputadores, operando como terminais nos pontos de serviço conveniados, e interligados aos sistemas transacionais de um banco contratante. O caráter inovador do canal, contudo, nunca esteve nestas tecnologias - de uso há bastante tempo difundido no ambiente bancário -, mas sim no desenvolvimento de novos arranjos negociais em torno ao seu uso. Por meio destes novos arranjos, constituiu-se rapidamente um canal intermediado de distribuição de serviços financeiros, envolvendo bancos públicos e privados e uma variedade de agentes parceiros, externos ao sistema bancário.

Irrelevantes em número até o início da década, os CBs experimentaram uma vigorosa expansão e se tornaram, no intervalo de poucos anos, o maior e mais capilarizado canal físico de distribuição de serviços dos bancos. Ao final de 2009, segundo dados oficiais do Banco Central do Brasil ${ }^{1}$, seu número alcançava 150 mil pontos de atendimento, superando em muito as demais dependências de atendimento bancário em operação no país, que naquela altura eram formadas por 19 mil agências, 6,7 mil postos de atendimento bancário (PABs) e 41 mil postos de atendimento eletrônico (PAEs) ${ }^{2}$.

Diante da dimensão do fenômeno, diversos estudos foram produzidos, sobretudo na década passada, investigando a forma como este novo canal de branchless banking se desenvolvia e demonstrando a importância por ele adquirida no mercado bancário brasileiro (Kumar et al., 2006; Lyman et al., 2006;

\footnotetext{
1 Dados disponíveis em http://www.bcb.gov.br. Os dados do Banco Central para o número de correspondentes costumam ser questionados, e são por vezes considerados superestimados, como será visto mais adiante. Isto não invalida o argumento que se quer ressaltar aqui, de que os correspondentes se tornaram o maior canal físico de atendimento dos bancos.

2 PABs são dependências bancárias instaladas no interior de empresas privadas, em geral de médio ou grande porte, ou de órgãos públicos, que se subordinam a uma agência geograficamente próxima e podem prestar os mesmos serviços que esta, assemelhando-se para todos os efeitos a uma agência. PAEs são dependências bancárias automatizadas, equipadas com terminais de autoatendimento e que não estão sujeitos aos horários de funcionamento das agências (COSIFE, s/d).
} 
Ivatury, 2006a, 2006b; Ivatury e Mas, 2008; Mas e Siedek, 2008; Mas, 2009; Bittencourt et al., 2006; Oliveira e Campello, 2006; Contel, 2007; Mohan, 2007; Soares e Melo Sobrinho, 2008; Diniz, 2007; Diniz et al., 2007, 2009a, 2009b; Jayo et al., 2012; Jayo e Diniz, 2013; entre outros).

Um importante ponto de consenso entre esses estudos é o diagnóstico de que os CBs, principalmente pelos baixos custos operacionais envolvidos em comparação aos canais físicos tradicionais, se oferecem como meio eficiente para se levar a oferta de serviços financeiros aos segmentos da população com menor renda, anteriormente pouco atendidos pelo sistema bancário. Se até o início da década de 2000 cerca de um terço dos 5561 municípios brasileiros não contavam com atendimento dos bancos por não oferecerem os retornos necessários ao investimento em agências e demais pontos de atendimento tradicionais, o desenvolvimento do novo canal de CBS fez decair essa proporção rapidamente a zero, permitindo levar cobertura bancária até mesmo às localidades mais pobres e distantes no interior do país (Soares e Melo Sobrinho, 2008), o mesmo ocorrendo nas áreas periféricas, bairros pobres ou mesmo favelas dos centros urbanos, que com a instalação de CBs ganharam acesso local a serviços bancários (Diniz, 2007; Ivatury, 2006a). Em função disso, o canal de CBs vem sendo considerado "um fator indiscutível para a democratização do acesso a serviços financeiros" (Diniz, 2007: 7), ou como "a mais promissora forma de se ampliar a oferta de serviços financeiros às populações com baixo 1DH' (Soares e Melo Sobrinho, 2008: 149).

Como efeito disso, a literatura em torno ao canal de CBs tem quase que invariavelmente suas preocupações no futuro do canal. Os estudos tratam de investigar de que forma o uso de CBS pode - ou deve - ser promovido ou regulado, a fim de surtir o melhor efeito possível em termos de inclusão financeira e social. Quais produtos financeiros ou microfinanceiros devem ser priorizados nele, ou de que forma os atuais arranjos regulatórios, negociais e tecnológicos que o sustentam poderiam ser aperfeiçoados, são questões em geral debatidas, que implicam complexa articulação de interesses, estratégias e competências entre bancos, Estado e uma variedade de demais agentes envolvidos na operação e uso do canal.

O presente artigo, na contracorrente, se propõe a olhar para o canal de CBs a partir de um olhar retrospectivo. Com o objetivo de refletir sobre os fatores históricos que levaram à formação do canal e fizeram com que ele adquirisse tamanha relevância, o artigo reúne diferentes notas, ou ensaios, sobre a história dos CBs no Brasil.

Sete ao todo, estas notas foram escritas entre 2007 e 2010 como parte da pesquisa de doutorado do autor, então em curso. Do ponto de vista metodológico, são resultado de revisão de literatura, anotações de campo do autor e entrevistas (mencionadas ao longo do texto) com atores sociais que participaram do processo de criação do canal. 


\section{Nota 1: Correspondentes Bancários no Brasil - Determinantes da Inovação}

"Correspondente bancário", na verdade, não é uma expressão de uso recente. Ao contrário, a expressão tradicionalmente designa um acordo entre dois bancos, um dos quais (o correspondente) aceita depósitos e presta serviços em nome de outro (o respondente) em praças ou regiões onde este último não dispõe de cobertura. Este tipo de acordo teria surgido para apoiar o comércio entre cidades da Europa medieval, eliminando o risco de transportar numerário (Crede, 1995). Esta foi uma fonte substancial de receita para bancos até por volta da década de 1980, mas com o advento de sistemas eletrônicos de pagamento passou a perder importância de forma gradativa, embora ainda seja bastante praticado em alguns países, especialmente na Europa (Crede 1995; Boot, 2003).

Se nesses países as práticas de correspondência bancária ainda estão próximas de suas origens, em outros, com destaque para o Brasil, novas modalidades têm surgido. Os avanços no uso de tecnologias de informação e comunicação criaram novas possibilidades de interconexão entre bancos e vários outros tipos de organizações, permitindo o desenvolvimento de modelos inovadores de correspondência, entre os quais o modelo surgido no Brasil é o mais bem-sucedido em termos alcance e escala (Diniz, 2007).

Conforme proposto por Tigre (2006) e por Diniz (2000), um dos aspectos mais importantes para se entender a emergência e difusão de inovações é o entendimento dos seus determinantes, ou seja, dos vetores que impulsionam o seu aparecimento. De acordo com esses autores, os determinantes de uma inovação podem ser classificados em de três tipos, a saber: aqueles relacionados à tecnologia, a "forças de mercado" e à regulação. Embora na prática estes determinantes se confundam, para entender uma inovação resulta útil pensá-los de forma isolada.

Do ponto de vista da regulação, embora a figura do correspondente já estivesse prevista na regulamentação do sistema financeiro brasileiro desde outubro de 1973, quando a Circular 220 permitiu a bancos comerciais firmar contratos com pessoas jurídicas para um conjunto ainda limitado de serviços (cobrança de títulos e a execução de ordens de pagamento em nome do banco contratante), o divisor de águas viria em 1999 e 2000, com as Resoluções 2640 e 2707 do Conselho Monetário Nacional (CMN), que expandiram substancialmente - leque de serviços possível de ser oferecido, além de estenderem a maior número de instituições financeiras a possibilidade de contratação de correspondentes. Hoje a atividade dos CBS se encontra regulada pelas Resoluções 3110 e 3156 do CMN, que consolidaram as normas anteriores com poucas modificações (Soares e Melo Sobrinho, 2008). 
A origem destas alterações no ambiente regulatório, determinantes para o crescimento do canal, pode ser atribuída ao fato de os correspondentes terem sido identificados como solução tecnológica para a implementação de programas sociais de complementação de renda, que àquela altura estavam começando a ser implantados em larga escala no Brasil (Diniz, 2007).

O maior papel indutor nesse sentido foi do Programa Nacional de Renda Mínima Vinculada à Educação, conhecido como Bolsa Escola, ${ }^{3}$ que envolvia transferências de renda a famílias pobres com filhos em idade escolar. Lançado em 2001, ${ }^{4}$ o Bolsa Escola tinha uma meta ambiciosa de alcançar, ainda no biênio 2001-2002, um total 5,7 milhões de famílias atendidas em todos os 5536 municípios brasileiros (Stal, 2002). Além disso, embora contemplasse todos os municípios do país, o programa estabelecia que teriam prioridade na implementação os municípios com menores índices de IDH (Licio, 2002).

Por outro lado, cumprir as metas do Bolsa Escola exigia a criação de um canal adequado de pagamentos, sem o qual não haveria como atingir as áreas de atendimento prioritário do programa, muitas delas sem cobertura do sistema bancário. Também se levava em conta a necessidade de se criarem mecanismos de pagamento que melhorassem outros tipos de remessas de recursos do governo federal (aposentadorias, seguro-desemprego, etc.), além de se universalizar o acesso a serviços financeiros básicos. A solução encontrada envolveu a expansão da rede de atendimento bancário, por meio do uso de CBs, naquelas localidades que não dispunham de outra forma de cobertura: "As mães recebem um cartão magnético da Caixa Econômica Federal Federal com o qual o benefício pode ser retirado no banco, casa lotérica, agência dos correios ou estabelecimentos credenciados" (Licio, 2002: 93-94).

Com efeito, em maio de 2002, Costabile (2002), ao avaliar os resultados das medidas que permitiram o início da utilização de correspondentes bancários, levava em conta critérios eminentemente sociais:

Hoje já são mais de 20 mil de pontos de atendimento onde a população pode obter benefícios como o Bolsa Escola e o Bolsa Alimentação do Governo Federal, as aposentadorias do INSS, PIS, e ainda efetuar o pagamento de contas como [as de] água, luz e telefone. [...] Cada beneficiário dos

\footnotetext{
${ }^{3}$ Em seguida ao Bolsa Escola, seriam lançados também os programas Bolsa Alimentação, Cartão Alimentação e Auxílio Gás. Em 2004, estes programas seriam unificados por ocasião da criação Bolsa Família.

${ }^{4}$ O programa foi instituído pela Medida Provisória 2.140, posteriormente convertida na Lei 10.219 de 11 de abril de 2001. Antes dele, outras políticas de renda mínima ou de complementação de renda já vinham sendo executadas, como foi o caso por ocasião da instituição da aposentadoria dos trabalhadores rurais independente de prévia contribuição previdenciária (1991) e de programas como o BPC - Benefício de Prestação Continuada (1996). O Bolsa Escola, no entanto, se destacaria em relação a essas iniciativas por seu caráter nacional e maior escala. Para uma análise detalhada dos programas de complementação de renda anteriores ao Bolsa Escola, ver Licio (2002).
} 
programas sociais do governo recebe um cartão magnético que é lido no terminal do correspondente bancário, que se comunica com os sistemas centrais e autoriza o pagamento, de forma barata e segura [...]. $\mathrm{O}$ correspondente bancário traz em seu bojo um forte processo de inserção social e cidadania, seja pela possibilidade [...] de transferência de benefícios governamentais aos cidadãos, seja pela melhoria da qualidade de vida, pelo aumento da autoestima e a criação de oportunidades de renda (Costabile, 2002: 1-2).

Embora as alterações no marco regulatório tenham sido feitas com a finalidade imediata de viabilizar a implementação do Bolsa Escola, elas também tiveram como efeito um crescimento do interesse estratégico dos bancos de varejo na figura do correspondente, na medida em que viam nela uma forma de criar alternativas para expansão de mercado e também para diminuir o fluxo de não cientes às agências, isto é, de pessoas que avolumavam as filas nos caixas demandando serviços de baixo valor agregado como é o caso, principalmente, dos pagamentos de contas e tributos (Diniz, 2007). Tem-se aí o principal determinante de mercado para a rápida expansão experimentada pelos CBs logo após sua regulamentação: o setor bancário enxergava neles uma oportunidade de constituir um canal alternativo às agências, que pudesse absorver a distribuição de serviços de menor valor agregado. As inovações incorporadas até a quarta onda tinham proporcionado aos bancos reduções de custos ao oferecer aos seus clientes canais alternativos ao das agências, tais como os ATMs e o internet banking. Estes canais, no entanto, não absorviam os "não-clientes", que continuavam avolumando as filas dos caixas. Isto vinha criando uma situação paradoxal: os bancos desenvolviam canais automáticos mais baratos para atender seus clientes, mas mantinham no seu canal mais caro - a agência - o recebimento de contas de não-clientes, justamente um dos serviços menos rentáveis para as instituições. Os correspondentes vieram ao encontro dessa necessidade, incentivando os bancos a adotarem-nos como inovação para serviços de menor valor agregado.

Por fim, do ponto de vista tecnológico, um aspecto relevante relacionado ao canal de CBs é o fato de as tecnologias específicas de informação e comunicação em que ele se baseia - terminais POS ou PCs, conectados aos sistemas transacionais dos bancos - não representam inovação em si, já estando há algum tempo consolidadas no setor bancário. O caráter inovador do canal está nos novos usos dessas tecnologias, proporcionados por novos tipos de arranjos e parcerias tornados possíveis entre bancos e um grande número de outros atores, muitas vezes dispersos geograficamente. Ainda assim, em boa medida o crescimento do novo canal foi possibilitado pela expansão da infraestrutura de telecomunicações no país, acelerada a partir da segunda metade da década de 1990. A expansão da telefonia celular também beneficiou a expansão dos correspondentes, que podem se utilizar de redes de GPRS (General Packet Radio Service, tecnologia de transmissão de dados da telefonia celular), além da Internet e de conexões via satélite. 


\section{Nota 2: Correspondentes Bancários: Dimensão do Fenômeno}

Esses determinantes impulsionaram uma expansão notável do canal ao longo da década de 2000, e o modelo resultante vem sendo considerado "único por seu alcance e escala, pela qualidade dos serviços oferecidos, e pela plataforma tecnológica que permite prestar esses serviços" (Kumar et al., 2006: 4). O gráfico 1, com dados oficiais do Banco Central do Brasil, mostra um crescimento forte e ininterrupto do número de pontos: entre 2000 e 2009, o número de CBs teria apresentado um crescimento da ordem de $30 \%$ anuais, enquanto o número de agências bancárias crescia ao ritmo de $2 \%$ ao ano. Com isto, ao final de 2009 o número de CBs totalizava 149,5 mil pontos, equivalentes a dois terços do total de pontos físicos de atendimento bancário instalados no país, e a quase oito vezes o número de agências bancárias em operação.

\section{Gráfico 1}

\section{Dependências de atendimento do sistema bancário brasileiro} (em milhares de pontos de serviço)

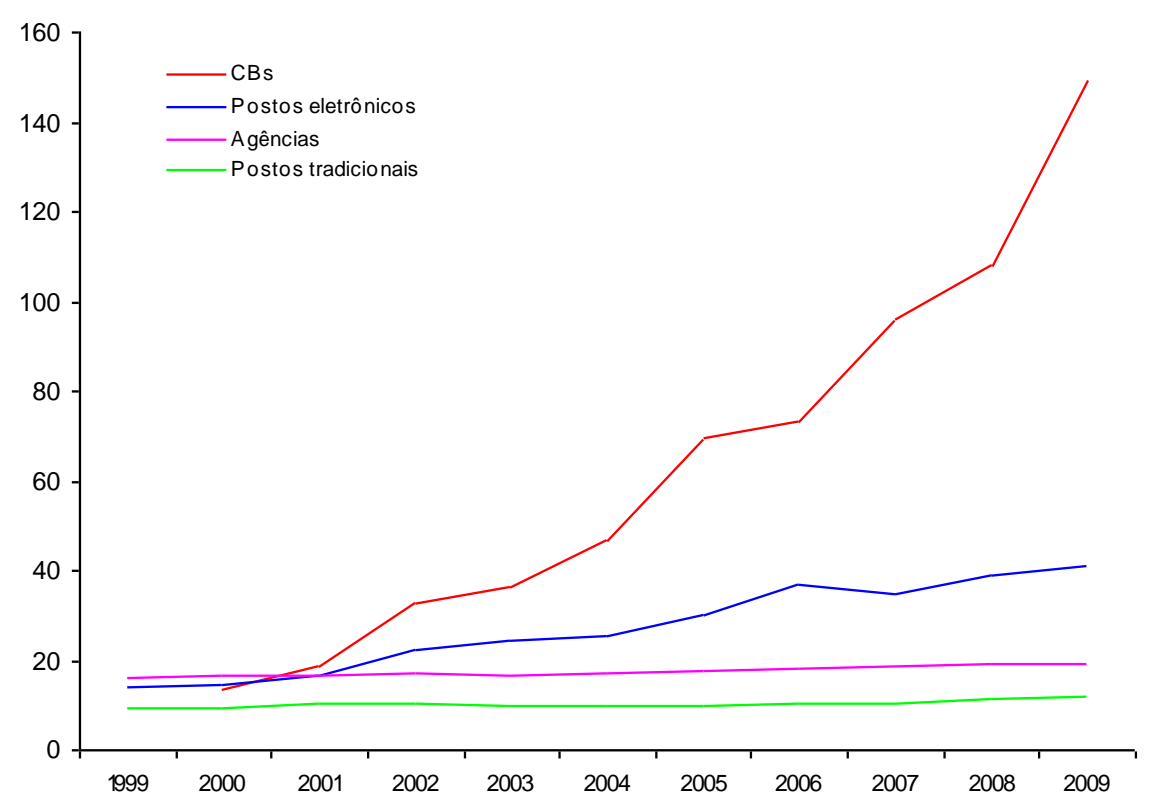

Fonte: construído com dados do Banco Central do Brasil (http://bcb.gov.br)

É preciso ressaltar, no entanto, que os dados oficiais do Banco Central do Brasil para o número de correspondentes são por vezes questionados, e costumam ser considerados superestimados. A principal razão para tanto, ressaltada por Diniz (2007), é uma confusão de nomenclatura induzida pela regulamentação dos correspondentes, que permite aos bancos cadastrar como seus CBs, junto ao Banco Central, instituições que na prática atuam de outras maneiras. É o caso de empresas promotoras de vendas que comercializam em nome de um banco contratos de crédito pessoal, em geral crédito consignado. Estas empresas mantêm equipes de vendedores de contratos de crédito (conhecidos no mercado como "pastinhas"), encarregados de prospectar clientes, 
preencher propostas de empréstimo e encaminhá-las a um banco para análise, em papel ou por meio de aplicação específica na internet. Outro exemplo são lojas de automóveis que encaminham a bancos contratos de financiamento de veículos. Embora a atuação destes agentes muitas vezes seja legalmente viabilizada por um contrato de correspondência bancária, eles na verdade guardam muito pouca semelhança com o conceito mais usual de correspondente, e com isto as estatísticas oficiais sobre o número de CBs se tornam imprecisas. Conforme ressalta Diniz (2007),

\begin{abstract}
Vale notar que não se trata aqui da definição de correspondente bancário na sua acepção mais usual, já que não se trata de um estabelecimento de varejo (farmácia, supermercado, etc.) servindo como canal de atendimento, mas sim de uma atividade de representação de vendas viabilizada por meio de um contrato de correspondente bancário. A legislação que regulamenta a atividade dos correspondentes permite que a mesma nomenclatura seja usada, na prática, para atividades significativamente diferentes (Diniz, 2007: 76).
\end{abstract}

Dados não publicados ${ }^{5}$ da Febraban (Federação Brasileira dos Bancos), por outro lado, permitem uma visão mais próxima do tamanho real do canal de CBs. Em outubro de 2009, a entidade projetava para o final daquele ano um total de 113 mil correspondentes habilitados no Brasil, dos quais 71 mil (62\%) seriam "correspondentes tradicionais", isto é, obedeceriam ao conceito usual de correspondente, e os restantes 42 mil (38\%) seriam "correspondentes negociais", responsáveis apenas pela coleta e encaminhamento de propostas de empréstimos. Note-se que mesmo a estimativa da Febraban para o total geral de correspondentes (113 mil pontos em dezembro de 2009) é significativamente inferior ao total de CBs estimado pelo Banco Central (149.500 pontos).

Outra razão para a distorção, embora não se encontre citada em estudos ou documentos publicados, seria a prática de determinados bancos de não comunicarem ao Banco Central o descadastramento de pontos de serviço, quando da rescisão de contratos de correspondente ${ }^{6}$. Pela regulação da atividade, cabe a cada banco cadastrar junto ao Banco Central os estabelecimentos habilitados como seus CBs, de forma que o dado do Banco Central para o número de correspondentes nada mais é do que a soma do número de estabelecimentos informados por cada banco. O cadastro é atualizado

\footnotetext{
5 Apresentados por Frederico Queiroz Filho, Diretor Setorial de Correspondentes da entidade, durante palestra no Seminário "Tecnologia e Finanças Inclusivas", na EAESP-FGV em 15 de outubro de 2009. A A apresentação disponível está http://www.ictformicrofinance.org/sites/default/files/tecnologia_e__financas_exclusivas.ppt (acessado em 12.12.2009).

6 A informação foi mencionada informalmente, em conversas com o autor, por executivos responsáveis por áreas de correspondentes de bancos.
} 
diretamente pelas instituições, por meio de sistema informático ${ }^{7}$. Não é raro, no entanto, que as instituições mantenham o registro de estabelecimentos que já não estão mais ativos como seus CBs, inflando com isso o cálculo oficial do número de correspondentes. O expediente seria usado para impedir que estes estabelecimentos sejam contratados como correspondentes por outro banco. Embora não haja restrições na regulamentação do canal que impeçam a contratação de um mesmo estabelecimento por mais de um banco, é habitual as instituições exigirem a exclusividade de seus correspondentes, de forma que, na forma como é operacionalizado na prática, o modelo brasileiro de CBs "prevê que um estabelecimento comercial apenas pode trabalhar com um banco". (Oliveira e Campello, 2006: 10).

Os mesmos dados da Febraban mostram, ainda, que dos 71 mil CBs, cerca de $70 \%$ pertencem a três instituições: Bradesco, Banco do Brasil e Caixa Econômica Federal, configurando um alto grau de concentração. Esse quadro de concentração tende a acentuar-se consideravelmente, com a incorporação pelo Banco do Brasil, em 2009, das operações de CBs do Banco Lemon e do Banco Nossa Caixa.

Os estudos disponíveis sobre o desenvolvimento do canal, via de regra, baseiam-se no total de pontos estimados pelo Banco Central (Kumar et al., 2006); Ivatury, 2006a, 2006b; Soares e Melo Sobrinho, 2008; etc). Se considerarmos as estimativas mais conservadoras da Febraban, a extensão do canal de CBs torna-se expressivamente inferior à usualmente considerada por esses estudos. Ao final de 2009, o canal seria constituído por 71 mil pontos de serviço, menos da metade dos $\mathbf{1 5 0}$ mil oficiais. Ainda assim, é possível considerar válido o diagnóstico presente na maioria desses estudos, de que o uso de CBS propiciou aos bancos uma expansão sem precedentes na sua rede de estabelecimentos. Mesmo com as estimativas mais conservadoras, a extensão do canal equivale a $50 \%$ das dependências bancárias instaladas no país, e a quase quatro vezes o número de agências.

\section{Nota 3: Correspondentes Bancários - Relevância}

Assim caracterizados seu surgimento e sua evolução recente, pode-se passar a discutir a relevância e o potencial do canal de CBs como canal de inclusão financeira, isto é, de distribuição de serviços financeiros adequados à população de baixa renda. O caráter social ou inclusivo do canal está presente desde as suas origens, uma vez que, como visto na Nota 2, seus determinantes regulatórios foram, na sua maior parte, dados por medidas voltadas a viabilizar

\footnotetext{
7 Utiliza-se para tanto o Sistema de Informações sobre Entidades de Interesse do Banco Central (Unicad), sistema de informações cadastrais unificado do Banco Central.
} 
programas sociais cuja implementação necessitava de uma infraestrutura de pagamentos com alcance nacional e grande capilaridade.

Com efeito, o canal de CBs é visto como grande oportunidade para o aumento da inclusão financeira no Brasil, levando serviços financeiros, sejam de pagamentos, crédito, poupança ou outros, a uma população tradicionalmente pouco atendida pelo mercado financeiro formal (Diniz, 2007; Kumar et al., 2006).

A fim de se entender as implicações do canal para a inclusão financeira, é conveniente fazer um rápido retrospecto sobre o mercado de serviços financeiros para a baixa renda no Brasil $^{8}$. A atividade microfinanceira não é recente no Brasil; ao contrário, as primeiras iniciativas na área datam do início da década de 1970. Entretanto, até o final da década de 1990 a atividade vinha sendo exercida por um número reduzido de organizações não-governamentais (ONGs) com atuação focada em microcrédito, sem alcançar escala significativa. Apesar de algumas experiências terem sido isoladamente bem-sucedidas, o tamanho dessa indústria não chegou a ser significativo, fazendo com que a atividade se mantivesse, na época, "quase inexistente" (Barone et al., 2002: 8). Além do quadro de instabilidade econômica com altas taxas de inflação que prevaleceu no país até 1994, a falta de um marco legal adequado que amparasse a atividade costuma ser apontado como grande fator de entrave ao crescimento da indústria de microfinanças, durante seus primeiros trinta anos de existência (Barone et al., 2002; Soares e Melo Sobrinho, 2008).

Esses entraves começam a ser afrouxados ao final da década de 1990. Além da estabilização do processo inflacionário, ocorrida em 1994, o ano de 1999 marca o início de mudanças no marco legal que ajudariam a alterar esse cenário e trariam consequências ao funcionamento do mercado de microcrédito e de microfinanças do Brasil. Entre essas medidas destacam-se: (i) a criação da figura legal das Oscips (Organizações do Terceiro Setor de Interesse Público), por meio da Lei do Terceiro Setor (Lei 9.790, de 23 de março de 1999); (ii) a criação das SCMS (Sociedades de Crédito ao Microempreendendor), com a Medida Provisória 1.894, de 23/11/1999 (depois convertida em Lei 10194, de 14/2/2001); (iii) um conjunto de resoluções do Banco Central voltadas a incentivar a atuação das cooperativas de crédito (Pinheiro, 2007); (iv) a Resolução 3.109 do Conselho Monetário Nacional (de 24/7/2003, posteriormente transformada em Lei 10.735, de 11/9/2003) passando a exigir dos bancos a destinação de $2 \%$ dos saldos em depósitos à vista para operações de microcrédito; e finalmente (v) a alteração do marco legal que regula a utilização de correspondentes bancários, conforme visto na Nota 1, a partir de 1999.

\footnotetext{
${ }^{8}$ Não é objetivo, aqui, traçar um histórico detalhado da atividade de microfinanças no Brasil. Para uma discussão mais detalhada ver, por exemplo, Barone e Sader (2008), Soares e Melo Sobrinho (2008), Monzoni Neto (2006), Monteiro (2005) ou Barone et al. (2002), entre outros.
} 
Sob influência dessas mudanças no ambiente regulatório, a estrutura do setor começaria, nos anos 2000, a se alterar consideravelmente. Se até o final dos anos 90 a indústria financeira era formada fundamentalmente por um número reduzido de ONGs, em seguida ela passaria a contar com uma variedade maior de participantes, tais como ONGs, Oscips, SCMs e cooperativas de crédito, além de bancos (Barone e Sader, 2008).

Com relação a estes últimos (bancos), tais mudanças no marco regulatório coincidiram, também, com um aumento do interesse dos bancos tradicionais de varejo pelo universo da baixa renda, verificado no período tanto no Brasil como no exterior (Rhyne e Otero, 2006). Segundo estes autores, pela concorrência nos seus mercados tradicionais, os bancos tradicionais de varejo, inclusive corporações internacionais, têm começado a se interessar pelos mercados de baixa renda. O "efeito demonstração" materializado por experiências de sucesso de alguns bancos pioneiros neste mercado teria contribuído para esse movimento.

Desta forma, os bancos tendem a aumentar a sua fatia de participação junto à clientela de baixa renda, entrando em um segmento até então dominado por ONGs e outros ofertantes não ligados ao sistema bancário (Mathison, 2007; Rhyne e Otero, 2006). Rhyne e Otero (2006) identificam três perfis distintos de bancos entrando nesse mercado, por meio de operações próprias ou em parceria com ofertantes tradicionais de microfinanças: (i) bancos locais com missão social, especializados no segmento, muitos deles com origem em ONGs; (ii) bancos comerciais (mainstream banks), que enxergam o segmento de baixa renda como uma linha de negócios visando à obtenção de lucros; e (iii) bancos públicos, cuja entrada na atividade responde a determinações de política social dos governos de seus países. Mathison (2007) acrescenta que a entrada dos bancos tem-se dado tanto de forma direta e independente como através de parcerias com ofertantes estabelecidos no mercado de microfinanças.

No Brasil, esse movimento também tem se feito presente. Vários são os casos de bancos que, por uma variedade de motivos, têm implementado estratégias de atuação no segmento de baixa renda. Diniz (2007) descreve três perfis básicos de bancos operando no segmento no Brasil que, embora sem coincidir exatamente, guardam bastante semelhança com aqueles apontados por Rhyne e Otero (2006) para o contexto internacional:

- Perfil 1 - Bancos públicos: Foram os primeiros a ingressar no segmento, e têm atuado nele de forma inserida nas políticas de inclusão social do Governo Federal. A Caixa Econômica Federal, o Banco do Brasil e o Banco do Nordeste do Brasil são os exemplos mais relevantes.

- Perfil 2 - Bancos com motivações de responsabilidade social: Um segundo grupo tem optado por entrar nos segmentos de menor renda como parte de políticas de responsabilidade social corporativa. São bancos privados 
nacionais e internacionais, que enxergam no segmento uma forma de investir em uma "imagem" de empresa socialmente responsável.

- Perfil 3 - Bancos com motivações de negócios: Um terceiro grupo possui motivações predominantemente comerciais, desenvolvendo produtos financeiros e modelos de negócios voltados a obter lucratividade no mercado de baixa renda.

Esse interesse dos bancos em expandir-se para os segmentos de menor renda estaria inserido no que Helms (2006) qualifica como sendo uma importante mudança de paradigma em curso no fornecimento de serviços financeiros à população de baixa renda. No paradigma tradicional, ou "paradigma de microfinanças", ofertar serviços financeiros adequados à população de menor renda era visto como atividade inerente a instituições microfinanceiras (IMFs), em geral especializadas em serviços de microcrédito, e operando fora do sistema financeiro. Essa forma de atuar estaria dando lugar a um novo paradigma, que a autora denomina de "sistema financeiro inclusivo". Neste paradigma novo, a oferta de serviços à população de baixa renda é vista como resultado de uma arquitetura financeira, tecnológica e de negócios, que permita integrar a população de baixa renda ao sistema financeiro.

Nesse mesmo sentido, Littlefield e Rosenberg (2004), assim como Littlefield et al. (2006), argumentam que, no seu modelo tradicional, as microfinanças estão fadadas a atingir apenas uma pequena fração da demanda por serviços financeiros das famílias de baixa renda. A maior parte das IMFs são "fracas, altamente dependentes de doações e incapazes de atingir alta escala e independência" (Littlefield e Rosenberg, 2004: 39). Nesse contexto, "para alcançarem seu pleno potencial, as microfinanças têm de tornar-se uma parte totalmente integrada do sistema financeiro de um país em desenvolvimento, ao invés de permanecerem confinadas ao nicho do terceiro setor" (p.39). Isto significa derrubar os muros entre as microfinanças e o sistema financeiro formal. Os autores enxergam dois "sinais alentadores" de que isso está em vias de acontecer nos países em desenvolvimento: (i) surgimento de parcerias operacionais entre bancos (detentores de tecnologia e funding) e IMFs (detentoras de conhecimento do segmento e metodologias de atuação no atendimento ao público de baixa renda), e (ii) o crescente emprego de tecnologias oriundas do setor bancário para reduzir os custos de distribuição das microfinanças, permitindo atender clientes de baixa renda de forma mais eficiente.

Para Helms (2006), um sistema financeiro inclusivo é composto de três "níveis": O primeiro deles (micro leve) diz respeito aos fornecedores, sejam eles bancos, IMFs ou outros agentes, que oferecem serviços financeiros à população de baixa renda. O segundo (meso level) é formado por uma infraestrutura tecnológica e uma arquitetura de negócios que garanta o alcance da oferta desses serviços e reduz seus custos transacionais. Finalmente, o macro level é formado pelas políticas governamentais e regulamentações que amparam a 
constituição dos outros dois níveis. Nessa ótica, a canal de CBs pode ser seguramente visto como componente importante do meso level, uma vez que em torno dele se cria uma arquitetura de negócios e uma infraestrutura tecnológica para "conectar" bancos e população de baixa renda e implantar estratégias privadas e políticas públicas de inclusão financeira.

No mesmo sentido, diversos estudos (Firpo, 2005; Stegman et al., 2005; Claessens, 2006; Undp, 2007; Weissbound, 2002) têm argumentado que a entrada dos bancos no segmento de baixa renda será possível com o uso de novos canais eletrônicos que permitam distribuir serviços financeiros de pequeno valor individual, com alta escala e baixos custos, a um público que não costuma ter acesso aos canais de distribuição bancários tradicionais. Outros diagnósticos, a exemplo do de Littlefield e Rosenberg (2004), já citado, são de que, por mais que as IMFs tradicionais possam ter um conhecimento apurado sobre as características ou necessidades do cliente de baixa renda, a sua atuação em escala é limitada por seus altos custos no acesso a clientes geograficamente dispersos e com retorno individual baixo (Kumar et al., 2006; Diniz, 2007). Estas avaliações corroboram fortemente o papel potencial do canal de CBs na construção de um sistema financeiro inclusivo mais amplo, compondo o que Helms (2006) denomina meso level.

\section{Nota 4: Redes Arrecadadoras como Precursoras do Canal de CBs}

Os bancos, no Brasil, além das funções bancárias clássicas de captação de recursos e intermediação financeira, tradicionalmente desempenham uma função adicional, qual seja a de servirem de agentes arrecadadores e de cobrança, isto é, intermediários do governo e de empresas concessionárias de serviços públicos na arrecadação de contas e tributos. Essa função foi atribuída ao sistema bancário na segunda metade da década de 1960, em um contexto de políticas voltadas à reforma e modernização do setor (Henrique, 2001).

Apesar de desempenhada pelos bancos em todo o território nacional desde então, historicamente a função arrecadadora se viu mais dificultada em algumas regiões do país do que em outras. Embora o setor bancário brasileiro seja considerado o mais desenvolvido da América Latina, existe uma grande disparidade regional na distribuição de suas agências e demais pontos tradicionais de atendimento (IPEA, 2009; Bermeguy e Luporini, 2006). Nesse contexto, a região Nordeste, em particular, é uma das mais prejudicadas. Segundo dados do Banco Central do Brasil $^{9}$, aproximadamente $75 \%$ das agências bancárias instaladas no Brasil em 2008 localizavam-se nas regiões Sul e Sudeste, caracterizando uma concentração da rede nas regiões mais ricas do país. Tal

\footnotetext{
${ }^{9}$ disponíveis em http://bcb.gov.br
} 
concentração se torna ainda mais clara se analisarmos a proporção entre número de agências bancárias e dados populacionais: usando dados do censo populacional de 2000, disponíveis em IBGE (2007), vemos que a região Nordeste dispõe de uma agência bancária para cada 21,2 mil habitantes, ao passo que nas regiões Sul e Sudeste essa proporção é de uma agência para cada 7,6 mil e 8,5 mil habitantes, respectivamente.

Essa situação contribuiu para que, a partir do início da década de 1990, começassem a surgir na região Nordeste empresas especializadas em montar redes arrecadadoras, oferecendo à população uma alternativa aos bancos como local de pagamento de contas. A experiência embrionária, que originaria o modelo de atuação dessas empresas, foi introduzida por uma conhecida rede de drogarias com sede em Fortaleza-CE, as Farmácias Pague Menos. A empresa iniciara uma estratégia de diversificação de produtos para além da venda de medicamentos, incluindo itens de perfumaria, conveniência e serviços (Castro e Santos, 2007), e, dentro desse contexto, firmou em 1991 um convênio com a Companhia de Águas e Esgotos do Estado do Ceará (Cagece), por meio do qual as lojas da rede tornavam-se pontos de recebimento de contas de água. No ano seguinte, convênios semelhantes seriam firmados pela empresa também com a Companhia de Energia Elétrica do Ceará (Coelce) e com a Teleceará (atualmente Oi Telemar, concessionária do serviço de telefonia fixa). Embora estes acordos com concessionárias envolvessem uma remuneração fixa por conta recebida, o principal objetivo da empresa era de outra natureza: consistia em aumentar o faturamento da rede ao atrair um maior fluxo de clientes para suas lojas, ao oferecer a possibilidade de pagar contas com maior comodidade, sem a necessidade de deslocar-se a agências bancárias muitas vezes distantes e superlotadas.

Com bons resultados, a experiência se alastrou rapidamente. Em pouco tempo, acordos semelhantes não apenas passavam a ser replicados por outras redes de varejo, sobretudo de drogarias ${ }^{10}$, como também foram ampliados dando origem a uma configuração de negócios que acabou conhecida pelo nome de "redes arrecadadoras". A diferença entre este modelo de atuação e o seu antecessor consistia em que, ao invés de empresas operando pontos comerciais próprios, a prática de firmar acordos de arrecadação foi adotada por empresas que passavam a se especializar em prospectar e contratar, para esse fim, estabelecimentos varejistas pertencentes a terceiros.

O modelo de negócios praticado por estas empresas passou a envolver tipicamente uma cadeia de três elos, a saber: (i) concessionárias de serviços públicos (água, luz, telefone) contratantes de serviços de arrecadação; (ii) as

10 Entrevistados citaram as redes de drogarias Guararapes (Rio Grande do Norte), Extra Farma (Maranhão, Ceará, Pará) e Araújo (Minas Gerais) como exemplos de empresas que replicaram a experiência ainda na primeira metade da década de 1990. 
chamadas empresas de arrecadação, cuja função consistia em contratar estabelecimentos comerciais, habilitando-os para o recebimento de contas, e (iii) uma rede arrecadadora formada por grande número destes estabelecimentos (farmácias, mercearias, minimercados, etc.). As concessionárias pagavam às empresas de arrecadação uma remuneração fixa por conta recebida, e parte dessa remuneração era repassada ao estabelecimento originador da transação (figura 1).

Figura 1

O modelo de negócios das redes arrecadadoras

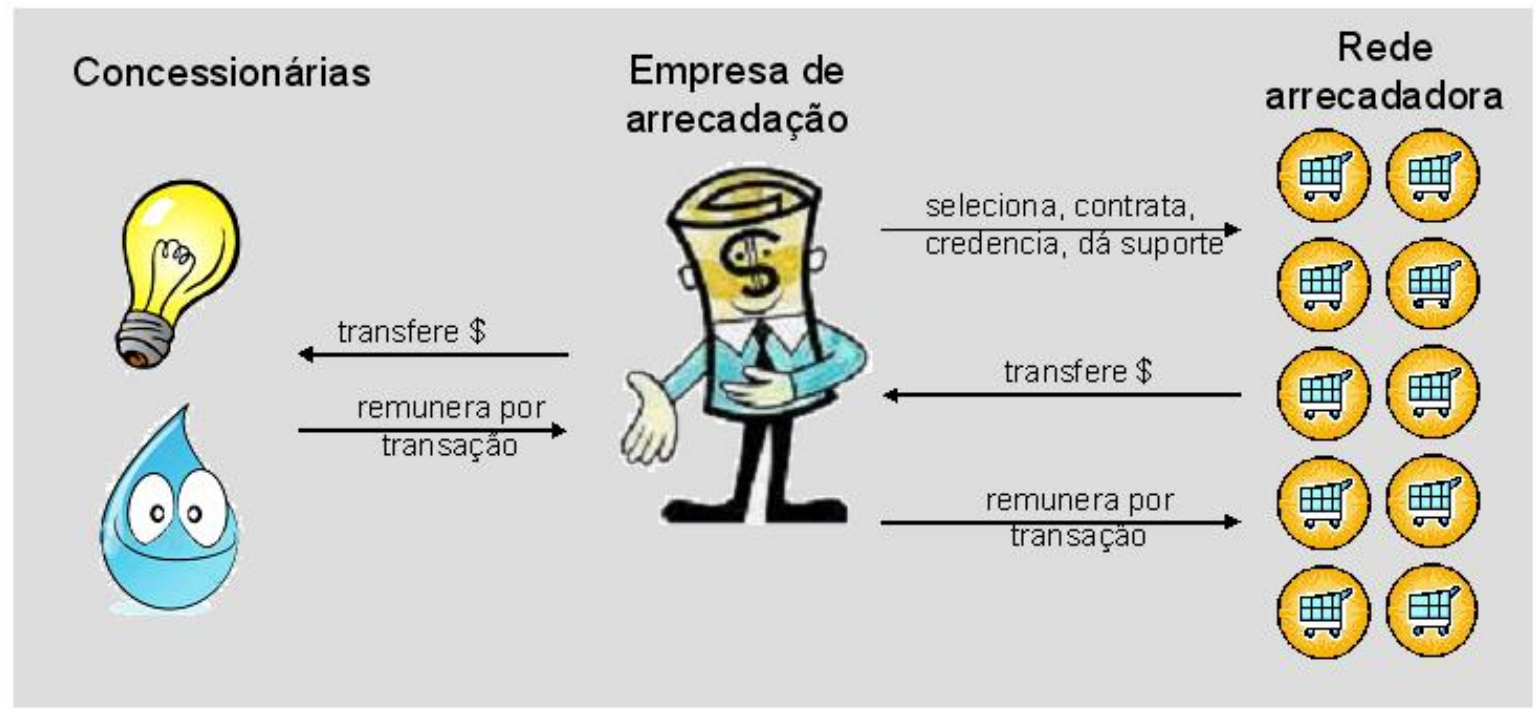

Fonte: elaboração própria

Somando-se às redes de drogarias que haviam sido precursoras do modelo, estas redes passavam a formar um extenso canal de arrecadação de contas, paralelo ao do sistema bancário. Por volta do ano 2000, já se contavam na região Nordeste pelo menos 17 empresas de arrecadação especializadas no negócio: empresas como Chegue\&Pague, ServicePag, PagFácil, Zazpag, Multipag, Pague Menos Arrecadação, entre outras, esta última por sinal pertencente aos sócios da rede de drogarias homônima, que havia sido pioneira na originação do modelo. Embora qualquer estimativa neste sentido seja imprecisa, uma vez que nunca foram produzidas estatísticas ou publicadas informações detalhadas sobre estas empresas, é possível que elas tenham chegado operar algo próximo a 10 mil estabelecimentos distribuídos pelo Nordeste, superando em cerca de cinco vezes o número de agências bancárias presentes na região.

Do ponto de vista tecnológico, por outro lado, a operação destas redes era rudimentar. Ao receberem o pagamento de contas, os estabelecimentos emitiam - respectivo recibo utilizando para tanto máquinas autenticadoras. Todo o processamento e a transmissão de informações eram feitos de forma artesanal: ao final do dia, os canhotos das contas recebidas em cada estabelecimento eram 
recolhidos por mensageiros (motoboys), para serem em seguida separados em lotes e enviados, também por mensageiros, às respectivas concessionárias, que faziam a baixa manual em seus sistemas. Em um segundo momento, passou-se a usar tecnologia de leitura ótica: neste caso, os canhotos das contas recebidas eram transportados a centrais de processamento mantidas pelas empresas de arrecadação, onde se centralizava a leitura de seus códigos de barra e se concentrava a informação em arquivos eletrônicos, em seguida enviados às concessionárias. Ainda assim, o processo era tecnologicamente rudimentar. Como relata um dos entrevistados, então diretor de duas destas empresas, as centrais de processamento consistiam de

[...] uns computadores dentro de uma salinha, com algumas pessoas passando a caneta ótica naqueles papéis todos [canhotos de contas recebidas no dia], aí concentrava-se num arquivinho que o motoqueiro levava em um disquete para cada concessionária. ${ }^{11}$

Note-se que o modelo das redes arrecadadoras não envolvia a participação de bancos: ao contrário, surgira como um canal de pagamento de contas alternativo ao oferecido pelo sistema bancário, suprindo deficiências de cobertura deste último. O modelo seria praticado sem maiores alterações até por volta de 2003. A partir desse ano ele passaria por uma importante evolução, com consequências diretas sobre o surgimento dos gestores de rede, conforme será visto na Nota 6.

\section{Nota 5: Início da Regulação}

Em um processo paralelo, ao final da década de 1990 começavam a tomar corpo os condicionantes que levariam à regulamentação e início da implantação do canal de CBs no Brasil. Como visto na Nota 1 , as origens regulatórias do canal estão em grande medida relacionadas à implantação de programas sociais de complementação de renda instituídos pelo Governo Federal, entre os quais o programa Bolsa Escola teve um papel de destaque. Implementar programas de transferências de recursos a famílias pobres, muitas delas vivendo em locais distantes de bancos, só seria factível se se criasse uma rede de pagamentos adequada, que suprisse a insuficiência de cobertura da rede de atendimento de agências e postos bancários. Também se levava em conta a necessidade de se melhorarem os canais de entrega de outros pagamentos do governo, como aposentadorias, seguro-desemprego e demais benefícios previdenciários.

${ }^{11}$ Entrevista com Camilo Bezerra, diretor da Multibank e Pagfácil, maio de 2007. 
Nesse contexto, a política posta em prática pelo Governo Federal a partir de 1999 envolveu dois componentes, a saber: de um lado promoveram-se mudanças em regulamentações do sistema financeiro vigentes desde a década de 1970, que disciplinava a contratação de correspondentes pelos bancos; de outro, duas empresas públicas federais foram mobilizadas pelo governo com vistas à implantação de extensas redes de correspondentes: a Caixa Econômica Federal (CEF) e a Empresa Brasileira de Correios e Telégrafos (ECT).

Como mencionado na Nota 1 , o uso de CBs já estava previsto na regulamentação do sistema financeiro desde 1973, quando a Circular 220 do Banco Central estabeleceu condições para que os bancos comerciais pudessem contratar pessoas jurídicas não integrantes do sistema financeiro nacional para prestarem em seu nome determinados serviços financeiros. Com mais de 25 anos de existência, no entanto, em 1999 esta regulamentação era bastante restritiva, por dois motivos. O primeiro dizia respeito ao leque de serviços permitido, limitado à execução de ordens de pagamento e à cobrança de títulos. O segundo estava relacionado ao fato de a autorização limitar-se a bancos comerciais. Desde o início da década de 1990, a grande maioria dos bancos brasileiros com carteira comercial haviam passado a se enquadrar como "banco múltiplo", categoria instituída em 1988 (Mendes, 1993). Isso significava, na prática, a exclusão da quase totalidade dos bancos brasileiros, e em particular os de maior porte, da possibilidade de contratar correspondentes ${ }^{12}$.

Nesse ambiente, um conjunto de alterações à regulamentação foram introduzidas por meio da Resolução 2640 do CMN, de 25 de agosto de 1999, depois aperfeiçoada pela Resolução 2707, de 30 de março de $2000^{13}$. As medidas tinham por tinham por objetivo tornar a regulamentação de 1973 menos restritiva, ao: (i) ampliar a faculdade de contratar correspondentes "aos bancos múltiplos com carteira comercial, aos bancos comerciais e à Caixa Econômica Federal"14 ; e (ii) ampliar o leque de serviços passíveis de serem distribuídos, que ficou assim estabelecido:

a) recepção e encaminhamento de propostas de abertura de contas de depósitos à vista, a prazo e de poupança; b) recebimentos e pagamentos relativos a contas de depósitos à vista, a prazo e de poupança, bem como a aplicações e resgates em fundos de investimento; c) recebimentos e pagamentos decorrentes de convênios de prestação de serviços mantidos

\footnotetext{
12 A classificação atual dos bancos brasileiros no que se refere ao tipo de instituição (bancos múltiplos, comerciais, de investimento e Caixa Econômica Federal) está disponível no website do Banco Central do Brasil, em http://www.bcb.gov.br/Fis/CODCOMPE/Tabela.pdf (acessado em 30/12/2009).

13 A Resolução 2640 limitava a atuação de correspondentes a praças desassistidas de agências ou postos de atendimento bancário, restrição que foi retirada pela Resolução 2707.

14 Resolução CMN 2707, de 30/03/2000. O texto integral da resolução está disponível em https://www3.bcb.gov.br/normativo/detalharNormativo.do?method=detalharNormativo\& $\mathrm{N}=100054612$ (acessado em 30/12/2009)
} 
pelo [banco] contratante na forma da regulamentação em vigor; d) execução ativa ou passiva de ordens de pagamento em nome do [banco] contratante; e) recepção e encaminhamento de pedidos de empréstimos e de financiamentos; f) análise de crédito e cadastro. ${ }^{15}$

Estas alterações tinham a função de abrir caminho para que duas empresas controladas pelo Governo Federal - a Caixa Econômica Federal (CEF), instituição financeira federal detentora do monopólio da exploração de loterias no país, e a Empresa Brasileira de Correios e Telégrafos (ECT), estatal que opera os serviços postais da União - fossem mobilizadas pelo governo para a implantação de serviços bancários em correspondentes. Ambas já contavam, pela natureza de suas atividades, com redes de estabelecimentos extensas e de abrangência nacional que, com a nova regulamentação, poderiam ser habilitadas como CBs. No caso da CEF, a rede era constituída por cerca 8,6 mil casas lotéricas presentes em 3,5 mil municípios, já interligadas por rede eletrônica aos servidores da instituição ${ }^{16}$. No caso da ECT, a rede era igualmente abrangente: aproximadamente 5,5 mil agências postais operadas pela própria empresa, além de um número equivalente de agências terceirizadas, operando por meio de contratos de franquias ${ }^{17}$.

Aproveitar esta infraestrutura já montada de pontos de prestação de serviços ao público, transformando as dependências de lotéricas e agências postais em locais de acesso a serviços bancários e, por conseguinte, ao recebimento de benefícios, foi identificado como a melhor alternativa para viabilizar a rede de pagamentos do Bolsa Escola e de outras transferências de recursos do governo às populações de localidades sem assistência ou pouco assistidas pelo sistema bancário. Nesse sentido, ambas as instituições - CEF e ECT - foram diretamente envolvidas na execução das políticas de inclusão financeira e social do Governo Federal.

\section{Nota 6: Implantação do Canal na Caixa Econômica Federal}

Instituição financeira pública com finalidade social, subordinada ao Ministério da Fazenda, a Caixa Econômica Federal possui a missão de "atuar na promoção da cidadania e do desenvolvimento sustentável do País, como instituição financeira, agente de políticas públicas e parceira estratégica do

\footnotetext{
15 Idem

${ }^{16}$ Número citado por Henrique Costabile, ex-diretor de tecnologia da CEF, em depoimento na Quinta Mesa Redonda do projeto "Tecnologia bancária no Brasil: uma história de conquistas e uma visão de futuro", realizado na FGV-EAESP em 9 de dezembro de 2009. Atualmente, o número de lotéricas é de cerca de 9,6 mil, de acordo com o website da CEF (consulta em janeiro de 2010).

17 Número mencionado em entrevista por Rodrigo Figueiró de Andrade, em janeiro de 2010. Atualmente o número de agências postais no país totaliza 12.644 , sendo 5.895 próprias e 6.749 terceirizadas, de acordo com o website da ECT (consulta em janeiro de 2010).
} 
Estado Brasileiro"18. Como parte de sua função social, é autorizada pelo Banco Central a atuar como banco e como sociedade de crédito imobiliário, detém o monopólio das operações sobre penhores civis; administra o FGTS (Fundo de Garantia por Tempo de Serviço) e é agente operador de pagamentos públicos, tais como aposentadorias e pensões. Além disso, também exerce desde 1962 o monopólio da exploração de loterias no país, arrecadando fundos direcionados ao orçamento da União para o financiamento de programas sociais. Para este último fim, coordena uma rede de 9,6 mil casas lotéricas, isto é, estabelecimentos privados contratados sob regime de licitação para distribuir serviços lotéricos em nome da instituição. Esta rede se soma a cerca 2,3 mil agências e postos operados diretamente pela instituição na prestação de seus serviços nãolotéricos.

Ao longo da década de 1990, a CEF vinha desenvolvendo estratégias de redução de custos através da intensificação o uso de canais eletrônicos no atendimento bancário, como forma de reduzir o volume de serviços transacionado pelos caixas das agências. Com esse objetivo a instituição promovera uma modificação no layout físico de suas agências, instalando antessalas equipadas com terminais de autoatendimento, de forma a reter ali a maior parcela possível do fluxo de clientes até então absorvido pelos caixas. 0 recurso encontrava seu principal limite, entretanto, no atendimento aos usuários da rede de agências da CEF que não eram absorvidos pela instituição. As antessalas eram capazes de absorver correntistas e demais clientes da instituição, conferindo-lhes acesso a serviços mediante o uso de cartões eletrônicos, mas não contemplava as necessidades do grande volume de nãoclientes que afluía à rede de agências para realizar transações de pagamento e recebimento em dinheiro, e que continuavam tendo de ser atendidos pelos funcionários dos caixas.

Nesse contexto, ainda na década de 1990 pôs-se em prática uma estratégia que consistia em habilitar a rede de casas lotéricas como canal complementar aos caixas para o recebimento de contas, absorvendo parte desse fluxo. Do ponto de vista tecnológico, dado que as lotéricas já estavam integradas em rede com a CEF para a venda de loterias, era necessário apenas promover adaptações de software, desenvolvendo aplicativo que as habilitasse também ao recebimento de contas. Esta solução passou as ser implementada pela CEF com a finalidade de desafogar o serviço de caixa das agências mais sobrecarregadas. As primeiras experiências de recebimento de contas em lotéricas datam de 1993, cerca de seis anos antes, portanto, das novas regulamentações para o uso de correspondentes bancários.

18 "Missão" reproduzida do website da instituição (acesso em janeiro de 2010). 
Embora inicialmente praticada como estratégia de redução de custos transacionais, esta solução acabou tendo o seu escopo substancialmente ampliado a partir de 1999, tornando-se um instrumento de promoção da inclusão financeira, a partir das novas diretrizes de política:

No final de 1999, saiu a determinação de que a CEF passasse a pagar os benefícios do Bolsa Escola em todos os municípios do Brasil, sem exceção. E tinha que pagar no próprio município, não podia pagar em outro lugar. Então fizemos um projeto relâmpago, pois tínhamos que implantar o serviço em todos os municípios brasileiros em um prazo de três meses ${ }^{19}$.

Para fazer frente a esse desafio, a CEF precisava constituir uma rede de pagamentos de abrangência nacional, e parte da solução para tanto passou pela utilização da infraestrutura já disponível na rede lotérica. As casas lotéricas foram habilitadas como CBs da CEF, com amparo na nova regulamentação de CBs, e com isto passaram a poder ser usadas como canal de distribuição de serviços financeiros - entre eles as transferências do Bolsa Escola -, recebendo uma remuneração fixa por transação efetuada. Entre agências, postos bancários e lotéricas agora habilitadas como CBs, a CEF pôde contar, em curto espaço de tempo, com aproximadamente 10 mil pontos de serviço instalados em 3,5 mil dos 5561 municípios do país.

No entanto, isto equacionava apenas parcialmente o desafio, uma vez que ainda restavam 1,5 mil municípios que não contavam com agências e postos nem tampouco com lotéricas. Acrescente-se a isso que as diretrizes de implementação do Bolsa Escola estabeleciam prioridade à implantação do programa para os municípios com menores níveis de IDH (Licio, 2008), justamente aqueles em que esta situação era mais frequente. Henrique Costabile, então diretor de tecnologia da instituição, relata que, em um primeiro momento, cogitou-se licitar a contratação de casas lotéricas nessas localidades, mas a solução foi logo descartada por razões operacionais e sociais:

Essas pequenas cidades, com, digamos, 1000 habitantes, não têm pessoas suficientes para fazer volume de jogo e viabilizar uma lotérica. Além disso, soaria muito estranho abrir lotéricas nesses lugares, porque a loteria tem uma expectância negativa, isto é, você perde dinheiro se não for sorteado..$^{20}$

Diante disso, a alternativa encontrada consistiu em constituir correspondentes bancários mediante a contratação de pequenos estabelecimentos comerciais existentes nessas localidades. Com isto habilitavam-se pela primeira vez estabelecimentos individuais como empórios,

\footnotetext{
${ }^{19}$ Henrique Costabile, em depoimento na Quinta Mesa Redonda do projeto "Tecnologia bancária no Brasil: uma história de conquistas e uma visão de futuro", na FGV-EAESP em 9 de dezembro de 2009.

${ }^{20}$ Idem
} 
mercearias, farmácias e postos de combustível, entre outros, como pontos de correspondente, que passariam a constituir a extensa rede de CBs não-lotéricos da CEF, hoje composta por aproximadamente 5,6 mil pontos, e que utiliza a marca "Caixa Aqui".

Dado que em sua grande maioria estes estabelecimentos estavam situados em localidades pequenas, distantes e sem infraestrutura de serviços, e que, portanto não contavam com fornecedores locais de tecnologia ou de redes de pagamento, toda a operação de implantação e gestão da infraestrutura tecnológica destes correspondentes foi assumida pela CEF. A gestão do canal foi confiada a uma área interna na estrutura da CEF, a Gerência Nacional de Canais Físicos Parceiros ${ }^{21}$, que se tornou responsável pela gestão da rede de correspondentes.

Para a infraestrutura tecnológica, utilizou-se solução proprietária diferente da utilizada em lotéricas, baseada no uso de um microcomputador (PC) operando como terminal de serviço dedicado em cada estabelecimento, e conectado aos sistemas da CEF via redes públicas de telecomunicação.

\section{Nota 7: Implantação do Canal na Empresa Brasileira de Correios} e Telégrafos

Assim como a CEF, a Empresa Brasileira de Correios e Telégrafos (ECT) também foi mobilizada pelo Governo Federal para a implantação de CBs no início dos anos 2000, com objetivos de inclusão financeira. Em outubro de 2000, o Ministério das Comunicações, ao qual a empresa está subordinada, editava a Portaria no 588, determinando a criação de um "Serviço Financeiro Postal Especial" que deveria se caracterizar "pela utilização da rede de atendimento da ECT para a prestação de serviços bancários básicos, em todo o território nacional, como correspondente de instituições bancárias ${ }^{122}$. Essa era a origem do projeto conhecido como Banco Postal, por meio do qual cerca de 5,8 mil agências dos Correios seriam habilitadas como correspondentes do Bradesco.

A Portaria estipulava que os serviços bancários em agências postais deveriam ser "implantados prioritariamente nos municípios desassistidos de atendimento bancário, como instrumento de inserção social", assim entendidos

\footnotetext{
${ }^{21}$ Conforme mencionado em entrevista em março de 2009 por Antonio Carlos Barasuol, gerente responsável pela área, esta gerência conta com aproximadamente 240 profissionais ("consultores regionais de canais") que atuam em conjunto com os gerentes das agências na identificação, contratação e gestão operacional da rede de correspondentes não-lotéricos.

22 Portaria 588 do Ministério das Comunicações, de 4 de outubro de 2000. Texto integral disponível em http://www.mc.gov.br/servicos-postais/legislacao/portarias/portaria-no588-de-04-de-outubro-de2000 (acessado em 28/01/2010).
} 
aqueles municípios que não dispunham de agências ou postos de atendimento bancário. Além disso, estabelecia-se que até 31 de dezembro de 2001 deveriam ser atendidos no mínimo 1000 municípios, e, até 31 de dezembro de 2003, todos os municípios desprovidos de agências e postos.

À edição da Portaria seguiu-se o processo de implantação do projeto. Em 2001 a ECT abriu licitação pública para a escolha de um banco parceiro, tendo saído vencedor o Bradesco. O acordo comercial envolvia um pagamento pelo Bradesco à ECT pela compra do direito exclusivo de oferecer serviços bancários nas agências postais, além de uma remuneração à ECT por transação efetuada (pagamento, recebimento, encaminhamento de proposta de abertura de conta, etc.).

Um executivo do Bradesco, à época diretor departamental da instituição para o Banco Postal, indica as motivações do banco ao associar-se ao projeto. Para o entrevistado, o principal interesse do banco consistiu na ampliação de mercado. Se a motivação do governo na implantação do projeto era eminentemente social, a do banco parceiro incluía estratégias de incorporação lucrativa de novos clientes em regiões distantes e em segmentos de renda até então pouco explorados:

A vantagem para o Bradesco, o que foi uma sacada muito interessante na época, é que a gente conseguiria oferecer serviços a custo variável. Por exemplo, quando nós abrimos uma agência do Banco Postal lá em Santa Rosa do Purus, no Acre, divisa com o Peru, oito dias de barco para chegar lá, nenhum banco iria abrir uma agência nessa cidade [...] porque jamais teria retorno sobre os 500 mil reais que teriam que ser investidos só na infraestrutura da agência, fora o custeio dela. Jamais o banco poderia ter retorno. Agora, com o Banco Postal, se nós temos lá um cliente, nós pagamos pelo serviço de um cliente. Se tivermos 10, pagamos pelo serviço de 10 , e assim por diante. Isso permitiu levar o serviço não só para essas localidades, mas também para as periferias das grandes cidades ${ }^{23}$.

Contrato foi assinado entre as duas instituições em setembro de $2001^{24}$, e as primeiras agências do Banco Postal foram instaladas em março de 2002 - com atraso, portanto, em relação ao originalmente estabelecido pela Portaria, que prevera o atendimento dos primeiros mil municípios já no final de 2001. Os cerca de seis meses entre a assinatura do contrato e o início da implantação foram o tempo que a ECT necessitou para providenciar infraestrutura tecnológica necessária. Vale observar que até a implantação do projeto, as agências postais não estavam conectadas em rede, e uma considerável parcela delas, sobretudo

\footnotetext{
${ }^{23}$ Entrevista com André Rodrigues Cano, diretor departamental do Bradesco, janeiro de 2007.

${ }^{24} \mathrm{O}$ contrato previa vigência do convênio por cinco anos após a instalação do último ponto, prazo que se esgotou em 2009. Nesse as duas instituições firmaram termo aditivo, prorrogando contrato até o final de 2011 .
} 
em localidades pequenas no interior do país, sequer dispunha de computadores. Assim, prover a infraestrutura necessária ao funcionamento do Banco Postal exigiu da ECT consideráveis esforços tecnológicos prévios à implantação dos serviços:

Montamos uma rede fechada interligando todas as agências. Foi a primeira vez que foi feito um movimento tão grande nos Correios em termos de implantação de tecnologia nas agências. Foi a primeira vez em que todas as agências foram interligadas em tempo real, e isso era uma enorme mudança ${ }^{25}$.

Como consequência, a ordem de implantação prevista na Portaria, priorizando municípios sem atendimento bancário, não pôde ser cumprida à risca:

Começamos a implantação pelos municípios desassistidos de atendimento bancário, e aí encontramos alguns problemas. Em algumas dessas localidades, as nossas agências não tinham na época a menor condição de serem implantadas, não tinham condições de utilizar um computador. [ ....] Todas as agências foram vistoriadas, e concluiu-se que algumas delas não teriam condições de funcionar como correio, quanto mais como correio e correspondente bancário. [...] Como resultado, dos 1000 primeiros municípios atendidos, cerca de 180 já possuíam agência bancária ${ }^{26}$.

Estes contratempos foram, no entanto, revertidos ao longo do processo, e a implantação foi concluída em 2004, em todas 5,8 mil agências postais próprias (não franqueadas) da ECT. Com isto, o Banco Postal passou a exercer com sucesso um papel de inclusão financeira em localidades até então desatendidas pelo sistema bancário. Este papel é enfatizado por um executivo do Bradesco:

O Banco Postal tem a característica de estar presente de uma forma muito forte nos municípios onde não existe banco. E o que a gente tem notado é que o banco postal tem mudado a cara de muitos municípios do país por conta da atividade econômica que ele passa a gerar. Porque antes você tinha as pessoas se deslocando até outros municípios para receber aposentadorias ou salários, e essas pessoas acabavam gastando dinheiro na outra localidade, e o município onde elas moravam não se desenvolvia. Com o Banco Postal, o dinheiro passou a circular naquele município, e aí a gente tem diversos

25 Entrevista com Rodrigo Figueiró de Andrade, gerente corporativo do Banco Postal, janeiro de 2010.

${ }^{26}$ Idem 
exemplos de municípios que passaram a se desenvolver muito em função $\operatorname{disso}^{27}$.

A impressão do executivo é corroborada por estudos como por exemplo o de Gual e Anzón (2008). Analisando dados referentes à economia dos 5561 municípios brasileiros no período 2000-2006, estes autores concluem que o Banco Postal teve influência positiva sobre a atividade empresarial (número de empreendimentos produtivos) e sobre o nível de emprego dos municípios atendidos.

\section{Nota 8: Expansão do uso do canal e o surgimento dos gestores}

Se em um momento inicial o canal de CBs estava ainda restrito às experiências de implantação na CEF e no Banco Postal, no ano de 2002 inicia-se um processo massivo de adoção do canal por bancos de varejo, tanto públicos como privados. Como resultado, ao final desse ano o número de CBs instalados no país já ultrapassava amplamente o de agências bancárias, configurando o início do processo de expansão acelerada do canal.

Diferentemente do que se verificara nos casos da CEF e do Banco Postal, em que a implantação fora diretamente influenciada por determinações governamentais, a entrada de novos bancos em 2002 foi decorrente de decisões concorrenciais das instituições. A partir das entrevistas realizadas, é possível distinguir duas motivações básicas, não excludentes, que estiveram presentes na adoção do canal pelos bancos: (i) redução de custos transacionais, e (ii) ampliação de mercado ou inclusão financeira. Essas diferentes motivações levaram a diferentes configurações operacionais adotadas pelos bancos na implantação e gestão de suas redes de CBs.

Uma primeira motivação estava ligada à redução de custos no atendimento bancário, por meio da diminuição dos volumes de serviço de caixa nas agências. Os bancos de varejo viviam o paradoxo de por um lado terem desenvolvido sofisticados canais eletrônicos para o atendimento a seus clientes, mas por outro continuarem a usar as agências, seu canal de distribuição mais caro, para a prestação de serviços de baixo valor agregado a não-clientes, especialmente o recebimento de contas. Em vista disso, o setor acabou

27 Entrevista com André Rodrigues Cano, diretor departamental do Bradesco responsável pelo Banco Postal, janeiro de 2007. 
encontrando nos correspondentes uma forma de constituir um canal menos dispendioso, e alternativo às agências para a prestação deste tipo de serviços ${ }^{28}$.

A estratégia consistia, portanto, na abertura de pontos de serviço de CBS em regiões do país já atendidas por agências bancárias - contrastando com as experiências anteriores de implantação, movidas por políticas governamentais voltadas explicitamente ao atendimento de áreas ainda não atendidas. Quatro dos bancos analisados (Banco do Brasil, Bradesco, Unibanco e Banco Real) iniciaram operações de CBs com este perfil em 2002, e um quinto (HSBC Brasil) faria o mesmo em 2004.

Embora seja difícil estabelecer uma cronologia precisa para a entrada destes novos bancos no mercado de CBs, uma das primeiras iniciativas relevantes neste sentido partiu do Banco do Brasil, ao firmar um acordo institucional com o grupo supermercadista Pão de Açúcar, com a finalidade de habilitar os terminais de caixa (check outs) das lojas do grupo como pontos de prestação de serviços do banco, com foco no recebimento de contas. Firmado ainda em 2001, o acordo começou a ser posto em prática em 2002 nas lojas do Grupo Pão de Açúcar no estado de São Paulo, e no ano seguinte expandido para o restante do país.

Do ponto de vista tecnológico e operacional, esta configuração de negócios se assemelhava às que já vinham sendo praticadas pela CEF com a rede lotérica, e pelo convênio entre Bradesco e ECT na implementação do Banco Postal: assim como nesses casos, o modelo se baseava na utilização de uma rede de estabelecimentos já montada. Em pouco tempo, este tipo de parcerias estratégicas passaria a ser adotado por outros bancos, firmando convênios com redes de varejo sempre com foco na prestação de serviços de arrecadação, na redução dos volumes de serviço de caixa e na redução de custos transacionais. Dentre as instituições estudadas, no Unibanco essa prática se tornou particularmente frequente, respondendo pela maior parte dos correspondentes operados pela instituição:

Os nossos serviços [em CBs] são voltados à arrecadação de contas, principalmente contas de consumo: água, luz, telefone e gás. Atuamos com parceiros, e eu cito o Magazine Luiza, o Ponto Frio e o Wal Mart, que são os três maiores, além de outras redes de varejo menores, com foco em quatro segmentos: supermercados e hipermercados, drogarias, lojas de materiais de construção e lojas de departamento ${ }^{29}$.

\footnotetext{
28 Segundo dados citados por executivos de bancos entrevistados, o custo médio de uma operação de recebimento seria de aproximadamente $R \$ 2,00$ nos caixas das agências, contra $R \$ 0,70 \mathrm{em}$ correspondentes (valores de 2010).

${ }^{29}$ Entrevista com Marcelo Garisto, gerente de correspondentes bancários do Unibanco, março de 2007.
} 
Além desta prática, no entanto, outra forma de implantação de redes de CBs, surgiu nesta época como forma de descongestionar agências e transferir serviços de arrecadação da CBs, envolvendo a contratação de correspondentes individuais, isto é, pequenos e médios estabelecimentos situados nas proximidades das agências.

Dado que o objetivo consistia em transferir para CBs parte do serviço de caixa já prestado por agências, a proximidade com agências era um atributo valorizado. Para tanto, as atividades de seleção e contratação destes estabelecimentos passaram a ser concentradas nas agências, normalmente prospectando correspondentes entre seus próprios clientes pessoa jurídica. Um executivo do Bradesco, responsável pela operação de correspondentes refere-se a este processo nos seguintes termos:

São estabelecimentos que já são conhecidos da agência, normalmente clientes da agência. Aí a agência oferece o serviço a eles [a contratação como correspondente]. Isso é feito pela agência porque, no fundo, quem conhece o cliente na ponta é o gerente do banco ${ }^{30}$.

Para prover a infraestrutura técnica da rede de correspondentes assim contratada, os bancos passaram a contratar empresas de captura e transmissão de transações eletrônicas (VANs), responsáveis instalar a infraestrutura tecnológica necessária à operação dos pontos. Diferentemente do que ocorrera com os correspondentes não-lotéricos da Caixa Econômica Federal ("Caixa Aqui"), localizados em geral em regiões distantes, e com pouca infraestrutura de serviços, nestes novos casos a abertura de CBs se dava em áreas urbanas e densamente bancarizadas, em que os bancos podiam contar com fornecedores dos serviços de infraestrutura técnica. Assim, configurava-se o surgimento de modelos de gestão de redes de CBs caracterizados pela delegação parcial da gestão da rede a gestores, em que o banco contratava os correspondentes e delegava sua gestão técnica a fornecedores desses serviços.

Uma segunda motivação por trás da adoção do canal de CBs depois das experiências iniciais da CET e do Banco Postal está ligada a estratégias de ampliação de mercado e inclusão de novos clientes ao consumo de serviços bancários. A estratégia envolve o uso de correspondentes bancários para se levar a oferta de serviços bancários básicos a parcelas da população até então pouco atendidas pelos canais bancários tradicionais. Tal estratégia, que conforme visto já estivera presente nas motivações do Bradesco ao associar-se ao projeto do Banco Postal, foi seguida em especial por duas instituições: o Banco Lemon e o Banco do Brasil.

30 Entrevista com Edmir José Domingues, gerente responsável pela operação de correspondentes bancários do Bradesco fora do Banco Postal ("Bradesco Expresso"), julho de 2009. 
O Banco Lemon era um banco privado, fundado em 2002, com a proposta de desenvolver produtos financeiros voltados a obter lucratividade no mercado de baixa renda. Seu principal diferencial consistia no fato de, ao contrário demais bancos de varejo, não dispor de agências como canal de atendimento ao público, concentrando todo o atendimento em CBs em regiões de baixa renda. O Banco do Brasil, por sua vez, em paralelo às suas estratégias acima mencionadas, de utilização de CBs para redução de custos transacionais, iniciou em 2003 uma operação voltada a atuar exclusivamente com correspondentes bancários no atendimento às populações de baixa renda em regiões desbancarizadas. Esta operação era conduzida por uma subsidiária criada para tal fim, denominada "Banco Popular do Brasil"31. Em ambas as instituições, a estratégia na abertura de pontos de serviço de CBs em áreas ou localidades em que elas não dispunham de agências ou outra infraestrutura administrativa para se encarregar da prospecção e contratação de estabelecimentos. Nesse sentido, a adoção de modelos de delegação parcial, com prospecção por agências, encontrava seu limite. Igualmente limitada se encontrava a adoção de modelos de uso de redes proprietárias, pelo simples fato de as duas únicas grandes redes com penetração junto em regiões desbancarizadas e de baixa renda - a postal e a de lotéricas - já estarem "ocupadas", respectivamente, pelo Bradesco e pela CEF. Essas limitações acabariam levando ambas as instituições à adoção de um modelo de delegação integral da gestão a gestores locais.

Esse tipo de estratégia, no entanto, encontrava entraves na regulamentação dos CBs. Apesar de terem impulsionado fortemente a adoção da inovação de CBs pelos bancos e o crescimento do canal em áreas já atendidas por agências, as Resoluções do Banco Central introduzidas em 1999/2000 ainda representavam, na prática, considerável restrição à contratação de correspondentes em áreas em que os bancos não dispusessem de infraestrutura administrativa. Isso ocorria porque, no seu artigo 2으, a Resolução 2707 impunha que os contratos referentes à prestação de serviços de correspondente incluíssem "cláusulas prevendo a vedação, à empresa contratada, de substabelecer o contrato, total ou parcialmente" 32 . Essa restrição só seria eliminada em março de 2003, pela Resolução 3110 do CMN, com consequências decisivas para a evolução do canal em áreas desbancarizadas e para a evolução dos modelos de gestão de rede.

O substabelecimento, vale a pena o parêntese, é um instrumento jurídico que, aplicado a contratos de prestação de serviços, possibilita à parte contratada nomear um substituto na execução dos serviços objeto do contrato, ao invés de

\footnotetext{
${ }^{31}$ Essa subsidiária, que tinha personalidade jurídica independente, seria reincorporada ao Banco do Brasil em 2008.

32 Resolução CMN 2707, de 30/03/2000, artigo 2으, inciso 2, alínea a. O texto integral da resolução está disponível

https://www3.bcb.gov.br/normativo/detalharNormativo.do?method=detalharNormativo\& $\mathrm{N}=100054612$ (acessado em 01/10/2009).
} 
executá-los ela própria. No caso de um contrato de correspondente bancário, o mecanismo possibilita que uma empresa detentora de um "contrato mãe" de correspondência com um banco, transfira a função de correspondente da instituição contratante a estabelecimentos comerciais terceiros por ela selecionados, integrando-os ao contrato. Ao proibir esse recurso, a regulamentação introduzida em 1999/2000 e vigente até 2003 impunha, na prática, que cada uma das pessoas jurídicas atuantes como correspondente deveria: (i) ser contratada diretamente por um banco, e (ii) desempenhar a função de CB suas próprias dependências ou estabelecimentos. A título de exemplo, a proibição do substabelecimento é apontada, entre outras possíveis razões estratégicas ou técnicas, como fator que limitou o número de agências postais que puderam ser habilitadas como correspondentes do Bradesco em função do contrato firmado em 2001 com a ECT. Ao não poder ser substabelecido pela ECT, o contrato não permitia habilitar as agências terceirizadas ou franqueadas, isto é, não operadas diretamente pela empresa.

Ao revogar a proibição do substabelecimento, a Resolução 3110 vinha ao encontro de interesses dos bancos que adotavam CBs como estratégia de expansão de mercado, uma vez que para eles resultaria oneroso administrar diretamente as atividades relacionadas à prospecção, contratação, instalação e administração de grande número de estabelecimentos de pequeno porte, espalhados no interior do país, distantes de suas agências, e em regiões em que os bancos não contavam com presença física ou infraestrutura administrativa. A possibilidade do substabelecimento permitiria desonerar essas atividades, ao transferi-las para empresas com infraestrutura própria e relacionamento com o comércio local, que se responsabilizariam por contratar manter em nome do banco o relacionamento com os estabelecimentos correspondentes.

Com isto, as empresas de arrecadação de que tratamos na Nota 4, nesta altura disseminadas em muitas destas regiões e detentoras de relacionamento já consolidado com suas redes de estabelecimentos locais, passaram a ser vistas pelos bancos como candidatas naturais para exercer essa função, possibilitando habilitar correspondentes em pontos do território onde as instituições não estavam presentes, sem incorrer em custos fixos. Para estas empresas, por sua vez, aliar-se a bancos significava ampliar as receitas obtidas com a operação de suas redes, ao incluir serviços de competência dos bancos, permitidos pela regulamentação dos CBs: recebimento de títulos de compensação (boletos bancários), abertura de contas correntes, depósitos e saques, encaminhamento de propostas de abertura de crédito, etc.

Por volta de 2002, já começava a ocorrer uma aproximação entre alguns bancos e estas empresas, com vistas a habilitar suas redes arrecadadoras como pontos de correspondência bancária. Um dos entrevistados, então responsável por duas empresas arrecadadoras, relata:

"Nessa época foi o nascimento do [Banco] Lemon. E houve um longo namoro, entre aspas, um namoro de negociação entre o Lemon e os sócios da 
Pagfácil, e entre o Lemon e os sócios da Multibank [...]. Mas esse namoro só pôde ser consumado de fato depois da Resolução 3110"33.

Da mesma forma, outro entrevistado relata que, embora já viesse mantendo entendimentos tanto com o Banco do Brasil como com o Banco Lemon, sua atuação efetiva como gestor só seria viabilizada a partir da edição da medida:

"A figura do gestor integral de rede apareceu junto com a normativa do Banco Central 3110. Antes não era permitida a figura do gestor de rede, e isso causava um problema muito grande, porque não é expertise do banco lidar com esse pequeno varejo [...] como canal de atendimento dele. E no caso de alguns bancos que tentaram fazer algumas coisas do gênero direto, principalmente quando era na região Nordeste e áreas de menor cobertura, isso tornava-se muito caro." ${ }^{34}$

Neste sentido, a Resolução 3110 veio a amparar, do ponto de vista regulatório, uma situação de negócios que já estava começando a se configurar de fato. Com efeito, em nota explicativa à medida por ocasião da sua publicação, - Banco Central afirma que a eliminação da vedação do substabelecimento se destinava a:

"[...] garantir que determinadas empresas, contratadas por instituições financeiras para a prestação de serviços do gênero e detentoras de relacionamento comercial com grande número de outras firmas, possam transferir as funções de correspondente a essas últimas, agregando novos pontos de atendimento bancário à população" (BCB, 2003, grifo nosso).

Na prática, permissão do substabelecimento pela Resolução 3110 do CMN acabou fazendo com que as antigas empresas de arrecadação, que até então vinham operando um canal de atendimento ao público paralelo ao do sistema bancário, se integrassem a ele. Para tanto bastou que, além dos contratos que já mantinham com concessionárias de serviços públicos, estas empresas firmassem também contratos de correspondência com bancos, substabelecendo-os a suas redes de estabelecimentos já montadas (figura 2 ).

Figura 2

Substabelecimento de contrato de correspondente

\footnotetext{
${ }^{33}$ Entrevista com Camilo Bezerra, diretor da Multibank e Pagfácil, maio de 2007.

${ }^{34}$ Entrevista com José Marcos Rasteiro, diretor da Netcash Brasil, maio de 2007.
} 


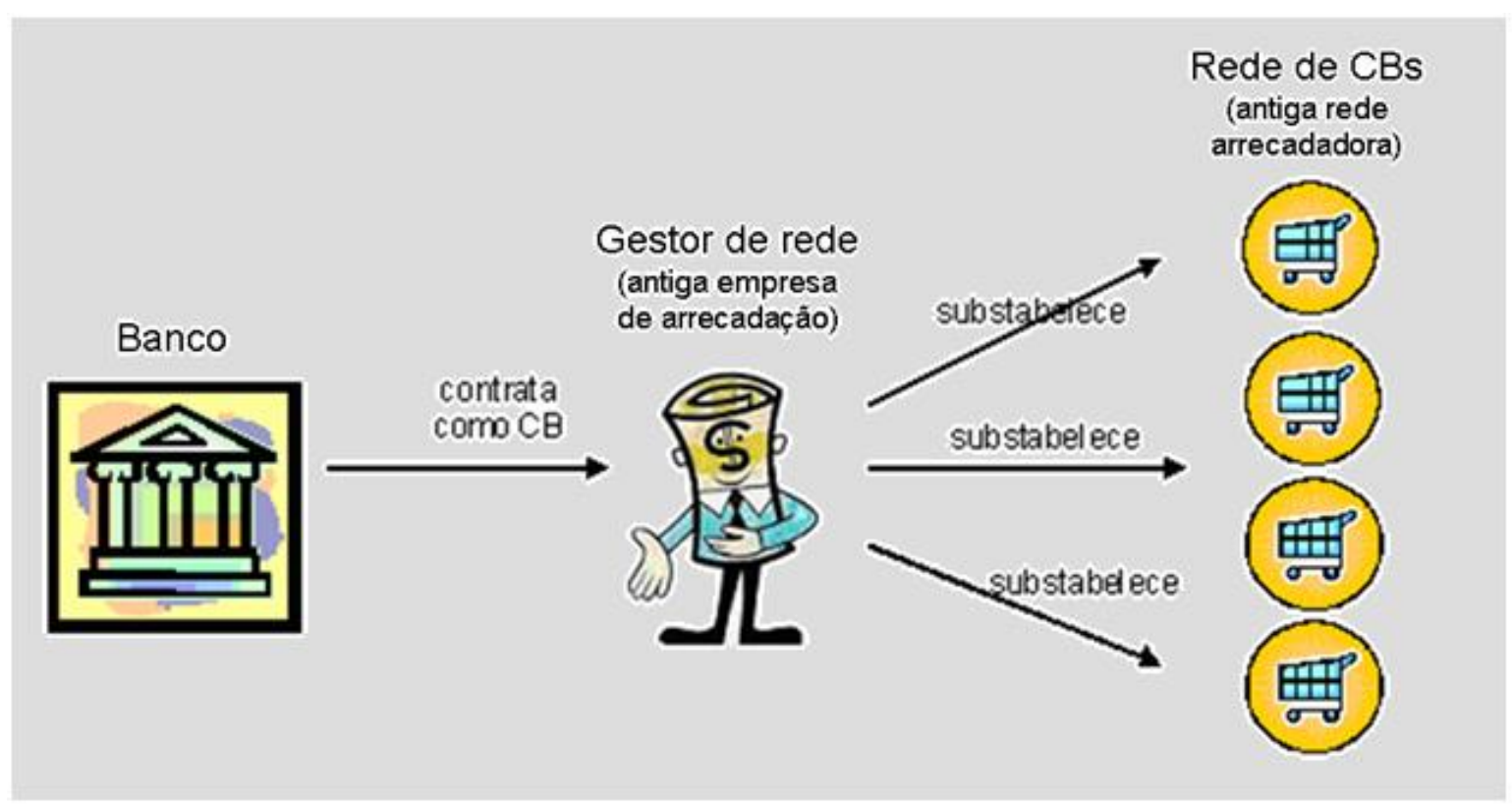

Fonte: elaboração própria

Esta incorporação pelos bancos, por outro lado, impôs uma urgente necessidade de modernização tecnológica às antigas redes arrecadadoras. As próprias concessionárias já vinham pressionando estas empresas para uma maior informatização, inclusive impondo prazos para a substituição dos processos até então manuais de captura, processamento e transmissão de dados referentes às contas arrecadadas em suas redes de estabelecimentos. A essa situação somouse 0 interesse dos bancos em utilizar essas redes como pontos de correspondentes bancários. Para tanto era necessário interligá-las eletronicamente aos seus sistemas transacionais, e garantir os requisitos bancários de segurança e confiabilidade na transmissão de dados. A solução encontrada envolveu uma tecnologia já em uso no sistema bancário, baseada na utilização de terminais POS (point of service) - semelhantes aos utilizados para pagamentos com cartões de crédito e débito.

Nascia desta forma um novo segmento de apoio aos bancos, especializado em montar e administrar redes de CBs integralmente - tanto no que se refere às atividades de integração negocial como às de integração técnico-logística. Se num primeiro momento os players se mantiveram os mesmos, apenas migrando do modelo de redes arrecadadoras para o de gestores de redes de CBs, com o tempo novas empresas iriam se somar ao grupo, já constituídas na forma de gestores.

Além destas últimas, um caso particular merece ser citado: o do Instituto Banco Palmas, organização do terceiro setor sediada em Fortaleza-CE e 
tradicionalmente atuante com microfinanças ${ }^{35}$, que assumiu em 2008 a função de gestor de rede de CBS Banco do Brasil, montando uma pequena rede - de aproximadamente 35 pontos no momento de finalização da pesquisa - com a particularidade de funcionarem não em estabelecimentos comerciais, mas em associações comunitárias e instituições de microfinanças. Embora com escala reduzidíssima, a experiência ilustra a capacidade revelada pelo modelo de incorporar diferentes tipos de agentes como gestores de redes.

O modelo resultante (figura 3) passou a envolver uma cadeia de três elos: (i) um banco contratante; (ii) um gestor de rede, contratado como correspondente pelo banco; e (iii) uma rede de CBS formada por estabelecimentos comerciais, selecionados pelo gestor e contratados por meio do substabelecimento do contrato mantido entre os dois primeiros. O gestor atua como um intermediário integral entre o banco e seus pontos, respondendo por todas as atividades de gestão da rede - negociais e de integração técnicologística. O banco remunera o gestor na forma de uma tarifa fixa por transação efetuada, e o gestor repassa parte dessa remuneração ao ponto originador da transação. Com isto, nasciam as primeiras configurações de delegação integral da gestão da rede de CBs a um gestor substabelevente.

\section{Figura 3}

\section{Modelo de gestor substabelecente}

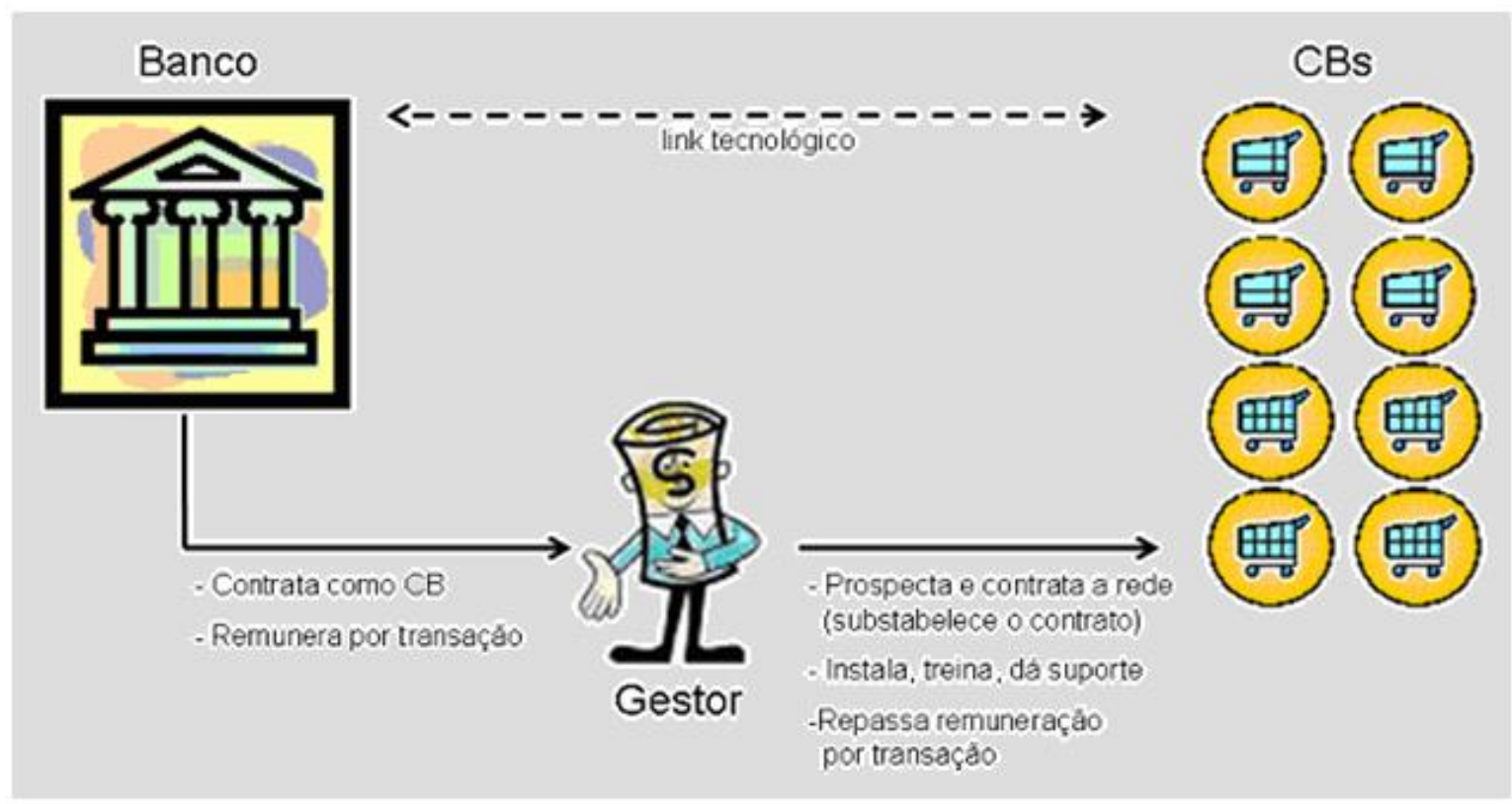

Fonte: elaboração própria

${ }^{35}$ Ver Jayo et al. (2009) para um relato do histórico e descrição das atividades da instituição. 


\section{Considerações Finais}

As sete notas aqui reunidas, ao jogarem um olhar retrospectivo sobre os correspondentes bancários, compõem um mosaico a partir do qual é possível reconstituir, ao menos em parte, as origens, condicionantes e principais eventos do processo histórico de formação desse importante fenômeno do mercado bancário brasileiro.

O modelo de CBs certamente terá um ciclo de vida, cujo auge parece terse dado entre o final da década de 2000 e o início da de 2010. Uma compreensão mais completa e abrangente do fenômeno, e da forma como influenciou e foi influenciado políticas públicas governamentais como as citadas neste trabalho, ainda está por ser feita. Nesse sentido, estas notas poderão quem sabe ser úteis a pesquisadores interessados na história desse canal (ou, de forma mais ampla, dos canais de branchless banking no Brasil) e das políticas públicas de inclusão social e financeira.

\section{Referências Bibliográficas}

Barone, Francisco Marcelo., Lima, Paulo Fernando., Dantas, Valdi., \& Rezende, Valéria. (2002). Introdução ao Microcrédito. Brasília: Conselho da Comunidade Solidária. 41p.

Barone, Francisco Marcelo., \& Sader, Emir. (2008) "Acesso ao crédito no Brasil: evolução e perspectivas". Revista de Administração Pública 42 (6): 12491267.

BCB (2003). Contratação de correspondentes de instituições financeiras no País (nota explicativa à Resolução 3110, de 30/03/2003). Disponível em http://www.bcb.gov.br/pre/denor/port/2003/1/\%5C3.110,\%20de\%2031\%20de \%20julho.asp (acessado em 12/08/2009).

Bemerguy, Camille Bendahan., \& Luporini, Viviane. (2006). Desenvolvimento financeiro e desigualdade de renda: evidências para o caso brasileiro. Rio de Janeiro: Universidade Federal Fluminense. Texto para discussão. Disponível em http://www.uff.br/econ/download/tds/UFF_TD207.pdf (acessado em 27/12/2008).

Bittencourt, Gilson., Magalhães, Reginaldo., \& Abramovay, Ricardo. (2005) Informação de crédito: um meio para ampliar o acesso dos mais pobres ao sistema financeiro. Pesquisa \& Debate, 2 (28): 203-248.

Boot, Arnoud W. A. (2003). "Restructuring in the banking industry with implications for Europe". In: Proceedings of the 2003 ElB Conference on 
Economics and Banking, Luxemburgo. Disp. em http://www.accf.nl/uploads/EIB\%20 Luxemburg\%20jan\% 202003.pdf (acessado em 20/12/2009).

Castro, João Bosco Barroso de., \& Santos, Neusa Maria Bastos F. (2007). "Gestão estratégica para redes de varejo farmacêutico: um modelo fundamentado no balanced scorcecard". 70 Congresso USP de Controladoria e Contabilidade. Disp. em http://www.congressousp.fipecafi.org/artigos72007/an_resumo.asp?con=1\&c od_trabalho=376 (acessado em 01/10/2009).

Claessens, Stijn. (2006). "Access to financial services: a review of the issues and public policy objectives". The World Bank Research Observer 21 (2): 207-240

Contel, Fabio Betioli. (2007). Território e finanças. Técnicas, normas e topologias bancárias no Brasil. Tese de doutorado. Universidade de São Paulo, Faculdade de Filosofia, Letras e Ciências Humanas.

COSIFE (s/d). Organização de instituições financeiras e assemelhadas: Cap. 4. Seção $1 . \quad$ Disponível em: http://www.cosif.com.br/mostra.asp?arquivo=mni010401. (acesso em 01/10/2009).

Costabile, Henrique. (2002). "Correspondentes Bancários". Banco Hoje, São Paulo, set.2002.

Crede, Andreas. (1995). "Electronic commerce and the banking industry: the requirement and opportunities for new payment systems using the internet". journal of Computer-mediated Communication, vol.3.

Diniz, Eduardo Henrique (2000). O uso da Web pelos Bancos: Comércio Eletrônico nos Serviços Bancários. Tese de doutorado. Fundação Getulio Vargas, Escola de Administração de Empresas de São Paulo.

Diniz, Eduardo Henrique. (2007). Correspondentes bancários e microcrédito no Brasil: tecnologia bancária e ampliação dos serviços financeiros para a população de baixa renda. Relatório de pesquisa. São Paulo: EAESP-FGV, $102 p$.

Diniz, Eduardo Henrique., Pozzebon, Marlei., \& Jayo, Martin. (2007). "Microcredit and correspondent banking in Brazil: what is missing? ". In: Ninth International Working Conference of the International Federation for Information Processing, workgroup 9.4, São Paulo.

Diniz, Eduardo Henrique., Pozzebon, Marlei., \& Jayo, Martin. (2009a). "The role of ICT in helping parallel paths to converge: microcredit and correspondent banking in Brazil". Journal of Global Information Technology Management, v. 12 , p. 80-103, 2009. 
Diniz, Eduardo Henrique., Pozzebon, Marlei., \& Jayo, Martin. (2009b). "Social innovations in the Brazilian banking area: using correspondents to increase microcredit delivery". 25th EGOS Colloquium, Barcelona.

Firpo, Janine. (2005). "Banking the unbanked: technology's role in delivering accessible financial services to the poor". In: MATHISON, S., org., Electronic banking with the poor: increasing the outreach and sustainability of microfinance through ICT innovations. Brisbane: The Foundation for Development Cooperation. Disponivel em: http://www.fdc.org.au/ Electronic\%20Banking\%20with\%20the\%20Poor/EBWTP\%20Full\%20Document .pdf (acessado em 20/8/2007).

Gual, Laia Bosch., \& Anzón, José. (2008). "Financial access and inclusion through postal networks: evaluating the experience of Brazil's Banco Postal". In: Anzón, José. Postal Economics in Developing Countries: Posts, Infrastructure of the 21st Century?. Berna: Universal Postal Union.

Helms, Brigit. (2006). Access for all: building inclusive financial systems. 1st ed. Washington: World Bank Publications.

Henrique, Jorge Luís (2001). Satisfação do usuário com as tecnologias de informação nos serviços bancários. Dissertação de mestrado. Universidade Federal do Rio Grande do Sul, Escola de Administração.

IBGE (2007). Tendências demográficas: uma análise da população com base nos resultados dos Censos Demográficos 1940 e 2000. Rio de Janeiro: Instituto Brasileiro de Geografia e Estatística. Disp. em http://www.ibge.gov.br/home/estatistica/populacao/temde ncia_demografica/analise_populacao/1940_2000/analise_populacao.pdf (acessado em 27/4/2008).

IPEA (2009). Transformações na indústria bancária brasileira e o cenário de crise. Relatório de pesquisa. Brasília: Instituto de Pesquisa Econômica Aplicada. Disp. em http://www.ipea.gov.br/sites/000/2/pdf/09_04_07_ ComunicaPresi_20_Bancos.pdf (acessado em 20/10/2009).

Ivatury, Gautam. (2006a). Brazil's banking correspondents. In: Mathison, Stuart., org., Electronic banking with the poor: Increasing the outreach and sustainability of microfinance through ICT innovations. Brisbane: The Foundation for Development Cooperation. Disp. em http://www.fdc.org.au/Electronic\%20Banking\%20with\%20the\%20Poor/EBWTP \%20Full\%20Document.pdf (acessado em 20/8/2008).

Ivatury, Gautam. (2006b). Using technology to build inclusive financial systems. CGAP Focus Notes n.32, January 2006.

Ivatury, Gautam., \& Mas, Ignacio. (2008). "The early experience with branchless banking". CGAP Focus Notes n. 46, April 2008. 
Jayo, Martín., \& Diniz, Eduardo Henrique. (2013). Um mapeamento descritivo dos modelos de gestão de redes de correspondentes bancários no Brasil. Revista de Administração (FEA-USP), v. 48, p. 621-634.

Jayo, Martín., Pozzebon, Marlei., \& Diniz, Eduardo Henrique. (2009). "Microcredit and innovative local development in Fortaleza, Brazil: the case of Banco Palmas". Canadian journal of Regional Science, v. 32.

Jayo, Martín., Diniz, Eduardo Henrique., Zambaldi, Felipe., \& Christopoulos, Tânia P. (2012). Groups of services delivered by Brazilian branchless banking and respective network integration models. Electronic Commerce Research and Applications, v. 11, p. 504-517.

Kumar, Anjali., Nair, Ajai., Parsons, Adam., \& Urdapilleta, Eduardo. (2006). Expanding bank outreach through retail partnerships: correspondent banking in Brazil. Washington: World Bank Working Paper n.85, 50p.

Licio, Elaine Cristina. (2002). A trajetória dos programas de renda mínima e bolsa escola no Brasil. Dissertação de Mestrado. Fundação Getulio Vargas, Escola de Administração de Empresas de São Paulo.

Littlefield, Elizabeth., \& Rosenberg, Richard. (2004). "Microfinance and the poor: braking down walls between microfinance and formal finance". Finance $\&$ Development 41 (2): 38-40.

Littlefield, Elizabeth., Helms, Brigit., \& Porteous, David. (2006). "Financial Inclusion 2015: "Four Scenarios for the Future of Microfinance". CGAP Focus Notes n. 39, Novembrer 2006.

Lyman Timothy R., Ivatury, Gautam., \& Staschen, Stefan. (2006). Use of agents in branchless banking for the poor: rewards, risks, and regulation. CGAP Focus Notes n.38, October 2006.

Mas, Ignacio. (2009). "The economics of branchless banking". Innovations 4 (2): 57-75.

Mas, Ignacio., \& Siedek, Hannah. (2008). "Banking through networks of retail agents". CGAP Focus Notes n. 47, May 2008.

Mathison, Stuart. (2007). "Increasing the outreach and sustainability of microfinance through ICT innovation". In: Mathison, Stuart., org., Electronic banking with the poor: Increasing the outreach and sustainability of microfinance through ICT innovations. Brisbane: The Foundation for Development Cooperation. Disp. em http://www.fdc.org.au/Electronic\%20Banking\%20with\%20the\%20Poor/EBWTP \%20Full\%20Document.pdf (acessado em 20/8/2009). 
Mendes, Aldo Luiz. (1993). "A reforma do sistema financeiro nacional". Estudos Avançados, São Paulo, vol.7, n.17, pp. 215-220.

Monteiro, Marcelo Nogueira Castro. (2005). Avaliação de desempenho de instituições microfinanceiras no Brasil: análise comparativa. Tese de doutorado. Universidade de São Paulo, Faculddade de Economia, Administração e Contabilidade.

Monzoni Neto, Mario Prestes. (2006). Impacto em renda do Microcrédito uma investigação empírica sobre geração de renda do Crédito Popular Solidário (São Paulo Confia), no Município de São Paulo. Tese de doutorado. Fundação Getulio Vargas, Escola de Administração de Empresas de São Paulo.

Mohan, C.P. (2007). "Products, Processes, and Institutions for Financial Inclusion: Experiences from Brazil \& South Africa". CAB Calling, Vol. 31, No. 3, pp. 103-109. Pune, India: Reserve Bank of India.

Oliveira, Juliana Servilha Gonçalves., \& Campello, Mauro. (2006). "Correspondentes bancários: tecnologia e inovação contribuindo para a inclusão social e resultados dos bancos". Anais do XIII SIMPEP - Simpósio de Engenharia de Produção, Bauru.

Pinheiro, Marcos Antonio Henriques. (2007). Cooperativas de crédito: história da evolução normativa no Brasil. Brasília: Banco Central do Brasil, 94p

Rhyne, Elizabeth., \& Otero, María. (2006). Microfinance through the Next Decade: Visioning the Who, What, Where, When and How. A Paper Commissioned by the Global Microcredit Summit 2006. November, 2006.

Soares, Marden Marques., \& Melo Sobrinho, Abelardo Duarte. (2008). Microfinanças: o papel do Banco Central e a importância do cooperativismo de crédito. Brasília: Banco Central do Brasil, 171p.

Stal, Israel Luiz. (2002). "Bolsa escola como alternativa de inclusão social". VII Congreso Internacional del CLAD sobre la Reforma del Estado y de la Administración Pública, Lisboa, Portugal, 8-11 Oct. 2002.

Stegman, Michael., Rocha, Marta., \& Davis, Walter. (2005). The role of technology in serving the unbanked. The Frank Hawkins Kenan Institute of Private enterprise, University of North Carolina.

Tigre, Paulo Bastos. (2006). Gestão da inovação: a economia da tecnologia no Brasil. São Paulo: Campus.

UNDP (2007). The United Nations Development Programme Annual Report 2007. Disp. em http://www.undp.org/publication s/annualreport2007//AR07-ENG.pdf (02/05/2008). 
Weissbound, Robert (2002). Banking on technology: expanding financial markets and economic opportunity. A report prepared for the Brooking Institution Center on Urban and Metropolitan Policy, the Financial Services Roundtable and the Ford Foundation. 42p. 